C:ID_DrivelWPDOCS\PROJECTS\Colombialjune2001 \submitlaer2002\co32902b.wpd

\title{
VOUCHERS FOR PRIVATE SCHOOLING IN COLOMBIA: EVIDENCE FROM A RANDOMIZED NATURAL EXPERIMENT*
}

\author{
Joshua D. Angrist, MIT \\ Eric Bettinger, Case Western Reserve \\ Erik Bloom, The Asian Development Bank \\ Elizabeth King, The World Bank \\ Michael Kremer, Harvard
}

April 5, 2002

"Special thanks go to the survey and field team in Bogota: Claudia Gonzalez, Marcela Monsalvo, Ana Gomez, and a dedicated team of interviewers from Javeriana University; in the US, we had the help of Emily Conover, Helen Lee, Brian Pasquinelli, and especially Cristina Estrada. We are also grateful to Jorge Estrada for help interpreting Colombian ID numbers, and to Jose Uribe for arranging for use of a testing site. Finally, thanks go to the World Bank and the National Institutes of Health for funding, and to Alberto Abadie, Jere Behrman, Adriana Kugler, David Levine, Lant Pritchett, Petia Topalova, and seminar participants at Banco de la Republica, Berkeley, Harvard, MIT, the NBER, Northwestern, and Princeton for comments. This document does not necessarily reflect the position of the Asian Development Bank and the World Bank. 


\begin{abstract}
$\underline{\text { ABSTRACT }}$
Colombia's PACES program provided over 125,000 pupils from poor neighborhoods with vouchers that covered approximately half the cost of private secondary school. Vouchers were renewable annually based on satisfactory performance. Since many vouchers were allocated by lottery, we use differences in outcomes between lottery winners and losers to assess program effects. Three years into the program, lottery winners were 15 percentage points more likely to have attended private school, had completed .1 more years of schooling, and were about 10 percentage points more likely to have finished $8^{\text {th }}$ grade, primarily because they were less likely to repeat grades. The program did not significantly affect dropout rates. Lottery winners scored .2 standard deviations higher on standardized tests. There is some evidence that winners worked less than losers and were less likely to marry or cohabit as teenagers. On average, lottery winners increased their educational expenditure by about $70 \%$ of the value of the voucher. Since winners also worked less, they devoted more total resources to education. Compared to an equivalent expansion of the public education system, the voucher program increased annual government educational expenditure by about $\$ 24$ per winner. But the costs to the government and to participants were probably much less than the increase in winners' earnings due to greater educational attainment.
\end{abstract}

Joshua Angrist

MIT Department of Economics

50 Memorial Drive

Cambridge, MA 02142

Erik Bloom

Asian Development Bank

6 ADB Avenue

Mandaluyong City, MM 0401

Philippines

Michael Kremer

Department of Economics

Littauer Center 207

Cambridge, MA 02138
Eric Bettinger

Department of Economics

Weatherhead School of Management

Case Western Reserve University

Cleveland, Ohio 44106-7206

Elizabeth King

Development Research Group

The World Bank

1818 H Street NW

Washington DC 20433 
While the academic controversy over school providers and school vouchers has raged most intensely in the US, private schools account for only about $11 \%$ of US enrollment (USDOE, 1998). Moreover, over half of American parents report that they are very satisfied with the public schools their children attend. In the developing world, in contrast, private enrollment as a proportion of total enrollment is 2-3 times higher than in industrialized nations (James, 1993). Problems with public schools are usually more severe in lowincome countries, since the quality and integrity of public-sector service-delivery is highly correlated with income levels (Rauch and Evans, 2000). In Indian schools, for example, a recent study found that one-third of headmasters were absent at the time of the researchers' visit (PROBE Team, 1999), while in Kenya, Glewwe, Kremer, and Moulin (2000) found that teachers were absent $28 \%$ of the time. The view that private schools function better than public schools in the developing world has prompted calls for governments in poor countries to experiment with demand-side financing programs such as vouchers (e.g, Psacharopolous, Tan, and Jimenez, 1986).

This paper presents evidence on the impact of one of the largest school voucher programs to date, the Programa de Ampliación de Cobertura de la Educación Secundaria (PACES), a Colombian program which provided over 125,000 pupils with vouchers covering somewhat more than half the cost of private secondary school. Vouchers could be renewed as long as students maintained satisfactory academic performance. Since many vouchers were awarded by lottery, we use a quasi-experimental research design comparing educational and other outcomes of lottery winners and losers. Subject to a variety of caveats, the resulting estimates provide evidence on program effects on participants that are similar to those arising from a randomized trial. As far as we know, ours is the first study of a private school voucher program in a developing country to take advantage of randomized treatment. ${ }^{1}$

\footnotetext{
${ }^{1}$ US studies in this mold include Green, Peterson, and Du (1996) and Rouse (1998), who evaluated a voucher lottery in Milwaukee. Rouse's estimates, which control for attrition, show modest increases in math scores among voucher recipients. Other US studies include Howell et al (2000), Myers et al (2000) and Bettinger (2001a), who evaluate various private scholarship programs. Hsieh and Urquiola (2002) examine a large-scale voucher program in Chile but do not take advantage of random assignment. Bellow and King (1993) assess a smaller program in Bangladesh. The literature on public/private comparisons in the US is extensive. Two recent studies are Evans and Schwab (1995) and Neal (1997). Cox and Jimenez (1991) compare public and private schools in Colombia and Tanzania, and Jimenez, Lockheed, and Paqueo (1991) summarize comparisons in five countries. See also the Patrinos and Ariasingham (1997) survey of demand-side financing in poor countries. Glewwe, Kremer, and Moulin (2000) and Behrman, Sengupta, and Todd (2000) use randomization to examine other educational interventions in developing
} 
A survey of three applicant cohorts shows no significant differences between lottery winners and losers in enrollment three years after application, with most pupils in both the winner and loser groups still in school. But lottery winners were 15 percentage points more likely to attend private schools rather than public schools. Moreover, lottery winners had completed an additional .1 years of school and were about 10 percentage points more likely than losers to have completed $8^{\text {th }}$ grade, primarily because they repeated fewer grades. Although high rates of grade repetition are a widely recognized problem in Latin America (see, e.g., Jacoby, 1994; and Psacharopoulos and Velez, 1993), reduced repetition need not indicate greater learning. We therefore administered achievement tests to a subset of the pupils surveyed. The test results suggest that, on average, lottery winners scored about 2 standard deviations higher than losers, a large but only marginally significant difference. The effect on girls is larger and more precisely estimated than the effect on boys.

In addition to increased educational attainment and academic achievement, there is also some evidence that the voucher program affected non-educational outcomes. In particular, lottery winners were less likely to be married or cohabiting and worked about 1.2 fewer hours per week (again, mostly a difference for girls). Both of these results suggest an increased focus on schooling among lottery winners.

While comparisons between winners and losers provide a simple strategy for assessing program impact, our survey indicates that only about $90 \%$ of lottery winners had ever used the voucher or any other type of scholarship, while $24 \%$ of losers received scholarships from other sources. It therefore seems reasonable to think of lottery win/loss status as an instrument for scholarship receipt in a two-stage least squares (2SLS) set-up. There is a strong first-stage here, though the relationship between voucher status and scholarship use is not deterministic. Instrumenting for scholarship use with lottery win/loss status suggests that scholarship use generated effects on grade completion and test scores that are roughly $50 \%$ larger than the reduced form effect of winning the lottery.

The last part of the paper presents a fiscal and cost-benefit analysis of the voucher program. Most lottery winners would have attended private school anyway, at least for a few years, and therefore reduced countries. 
their educational expenditure in response to the program. On the other hand, voucher winners who were induced to switch from public to private schools greatly increased their educational expenditure, since the voucher covered only about half the cost of private school. On balance, winners' gross school fees exceeded those of losers by about $70 \%$ of the amount they received from the voucher. Winners paid greater fees because they were more likely to go to private schools, and because some winners who would have gone to private schools anyway switched to more expensive private schools. Moreover, lottery winners worked less, so that, on balance, households winning the lottery actually devoted more resources to education than the voucher face value. We also estimate that the voucher program cost the government about $\$ 24$ more per winner than the cost of creating a public school placement. These costs to participants and the government are likely to have been more than outweighed by the benefits of the voucher to participants -- in the form of the economic return to increased educational attainment and test scores.

A number of channels could potentially account for the PACES program's effects on participants. The program clearly shifted some participants from public to private school, and pupils who shifted may have benefitted from the opportunity to attend private schools. There is also evidence that some pupils who would have attended private school anyway were able to attend more expensive private schools. Finally, voucher recipients may have had greater incentives to focus on school because vouchers could only be renewed for those pupils who did not repeat grades.

The paper is organized as follows. Section I provides background on education in Colombia and describes the PACES program in more detail. Section II discusses data and presents descriptive statistics from our survey. Section III discusses the effect of the program on school choice and basic educational outcomes. Section IV reports the effect of winning a voucher on test scores and non-education outcomes. Section V discusses the use of lottery win/loss status as an instrument to identify the causal effect of receiving a scholarship. Finally, Section VI looks at the effect of the program on household and government expenditure, and compares program costs with the benefits to participants. 


\section{Background}

The Colombian government established the PACES program in late 1991 as part of a wider decentralization effort and in an attempt to expand private provision of public services (King et al, 1997). The program, which was partly funded by the World Bank, was also motivated as an effort to quickly expand school capacity and to raise secondary school enrollment rates (King, Orazem, and Wolgemuth, 1998). ${ }^{2}$ Although $89 \%$ of Colombia's primary-school age children were enrolled in 1993 , only $75 \%$ of the eligible population was enrolled in secondary schools. Among children of eligible age in the poorest quintile of the population, $78 \%$ were enrolled in primary school, but only 55\% were enrolled in secondary school (Sanchez and Mendez, 1995; note that secondary school covers grades 6-11 in Colombia.)

The PACES program targeted low-income families by offering vouchers only to children residing in neighborhoods classified as falling into the two lowest socioeconomic strata (out of 6 possible strata). Applicants had to submit a utility bill to establish residential location and voucher eligibility. Targeting was enhanced by restricting vouchers to children who attended public primary schools. Almost half of children from the richest income quintile attended private primary schools. Studies by Morales-Cobo (1993) and Ribero and Tenjo (1997) suggests that the targeting was largely effective in Bogota.

PACES vouchers were worth only about US\$190 at the time of our survey. The maximum voucher value was set initially to correspond to the average tuition of low-to-middle cost private schools in Colombia's three largest cities. Schools charging less than the vouchers' face value received only their usual tuition. PACES vouchers became less generous over time because they did not keep up with inflation, and hence recipients had to supplement vouchers with additional payments to cover school fees. Our survey data show matriculation and monthly fees for private schools attended by voucher applicants in 1998 averaged about

\footnotetext{
${ }^{2}$ PACES was launched in November 1991 with advertisements in print and on radio soliciting applicants in participating cities (Calderon, 1996). A World Bank (1993) report on Colombian secondary schools notes that most schools operated 2 or 3 shifts and that some towns have little room for additional pupils in spite of projected enrollment growth. Other problems mentioned in the report include poor primary-school preparation, weak school management, lack of teacher preparedness, lack of textbooks, and shortages of other supplemental materials. The early 1990s was a general period of reform and liberalization in Colombia; see, for example, Kugler (1999).
} 
$\$ 340$, so most voucher recipients supplemented the voucher with private funds. By way of comparison, the average annual per-pupil public expenditure in Colombia's public secondary school system in 1995 was just over $\$ 350$ (DNP, 1999), and public school parents in our sample typically paid tuition or fees of roughly $\$ 58$. Per capita GNP in Colombia is now around \$2,280 (World Bank, 1999).

To qualify for a voucher, applicants must have been entering the Colombian secondary school cycle which begins with grade 6 , and be aged 15 or under. Prior to applying, students must already have been admitted to a participating secondary school (i.e., one that would accept the voucher). ${ }^{3}$ Participating schools had to be located in participating towns, which included all of Colombia's largest cities. Just under half of private schools in the 10 largest cities accepted vouchers in 1993.

Participating schools tended to serve lower-income pupils, and to have lower tuition than nonparticipating private schools. Schools with a vocational curriculum were also over-represented among those in the program. Participating private schools included for-profit schools, religious-affiliated schools, and schools run by charitable foundations. Initially, vouchers could be used at both for-profit and non-profit schools, but after 1996, for-profit schools were excluded. ${ }^{4}$ The number of vouchers in use in any one year peaked at roughly 90,000 in 1994 and 1995. There were approximately 3.1 million secondary school pupils in Colombia in 1995, 37\% of whom attended private schools. In Bogota, roughly 58\% of 567,000 secondary school pupils attended private school.

Test score comparisons reported by King et al (1997) show achievement levels in participating private schools were very close to those in public schools, though significantly below achievement levels in nonparticipating private schools. Pupil-teacher ratios and facilities were similar in public and participating private schools, and many of the teachers in the private schools most likely to participate in the PACES program are

\footnotetext{
${ }^{3}$ Background information in this section is taken from King et al (1997), Calderon (1996), and unpublished ICETEX documents.

${ }^{4}$ This was due largely to reported problems with low-quality for-profit schools created to exploit the vouchers. Calderon (1996) notes that even before the non-profit restriction was imposed, only $15 \%$ of Bogota's voucher students attended such institutions.
} 
moonlighting or retired public school teachers. Non-participating private schools had lower pupil-teacher ratios and better facilities. Clearly, then, relatively elite private schools opted-out of the PACES program. Reasons for this may include delays in payment of voucher funds to schools and bureaucracy in the Colombian Institute for Education, Credit and Training Abroad (ICETEX), which ran the program. Moreover, vouchers were insufficient to cover much of the tuition at more expensive schools, and some school managers probably viewed the prospect of an influx of pupils from low-income backgrounds as undesirable. On the other hand, many private schools in Colombia serving low-income populations apparently welcomed the PACES program.

Voucher recipients were eligible for automatic renewal through eleventh grade, when Colombian high school ends, provided the recipient's academic performance warranted promotion to the next grade. Students failing a grade were supposed to be dropped from the PACES program. Figures from Calderon (1996) show that, on average, $77 \%$ of recipients renewed their vouchers, and estimates from our data are similar. By way of comparison, the national high school promotion rate was about $70 \%$. Students who transferred from one participating private school to another could, in principle, transfer the voucher to the new school. In practice, however, our survey suggests many students who transferred schools after winning lost their vouchers.

Cities and towns used lotteries to allocate vouchers when demand exceeded supply. Municipal governments paid $20 \%$ of the voucher cost, while the central government paid $80 \%$. Each municipality decided how many vouchers to fund, subject to a maximum allocated to towns by the central government. This allocation was determined by estimating the shortfall between primary school enrollment and the available space in public secondary schools. Voucher award rates therefore varied considerably by city and year, depending on the ratio of applicants to available vouchers. Regional ICETEX offices worked with individual municipalities to determine the number of vouchers to be funded, to check school requirements for participation, and to monitor implementation of the program. The Bogota ICETEX office provided software and instructions to regional offices for the purposes of random selection of applicants in cases of over- 
subscription. We obtained copies of lists of lottery winners and losers from ICETEX offices. ${ }^{5}$

\section{The Applicant Survey}

\section{A. Descriptive Statistics}

Beginning in the summer of 1998, we interviewed roughly 1,600 PACES applicants, stratifying to obtain approximately equal numbers of winners and losers. Interviewing was limited to the 1995 and 1997 applicant cohorts from Bogota and the 1993 applicant cohort from Jamundi, a suburb of Cali. These years and cities were chosen for a combination of scientific and practical reasons. The largest and longest-running voucher program was in Bogota, and our survey team is based there. Cali is Colombia's second largest city and therefore also important, but almost no Cali applicants reported phone numbers, so we concentrated on a suburb, Jamundi. Telephones were used for the majority of interviews, primarily to reduce costs, but also because of interviewer safety and logistical considerations. In principle, the lottery was random within localities and conditional on whether households have access to a telephone (even if it is a neighbor's phone), the results should therefore yield internally valid estimates of the causal effect of the program on voucher applicants with access to a telephone in surveyed cities. Over $80 \%$ of applicants had access to a phone, and in the Bogota 1995 cohort, $88 \%$ had access to a phone.

Table 1 reports descriptive statistics for the sampling frame, attempted contacts and completed interviews. ${ }^{6}$ There were 6,156 applicants in the three applicant cohorts of interest. We attempted to interview almost 3,000 applicants, obtaining an overall response rate of 54\% and a response rate of almost $61 \%$ for the 1997 Bogota lottery. The higher response rate in the most recent lottery is not surprising since contact information for 1997 applicants is more recent. Interviews were completed with 55\% of lottery winners and $53 \%$ of lottery losers. Although this response rate is far from ideal, the fact that winners and losers were

\footnotetext{
${ }^{5}$ In a few cities, the local ICETEX office assigned vouchers based on pupils' primary school performance instead of
} randomly.

${ }^{6}$ The data appendix in our working paper (Angrist et al, 2001) provides additional information about the survey. 
almost equally likely to be interviewed is encouraging because the question of sample selection bias turns on whether voucher status is correlated with response probabilities (see, e.g., Angrist, 1997). Because response probabilities are virtually uncorrelated with voucher status, there should be little bias from our failure to interview all applicants. ${ }^{7}$

The typical applicant was about 13 years old at the time of application, while average age on the survey date varied from 13 for 1997 applicants to 17 for 1993 applicants. About half of the applicants were male. Roughly $85 \%$ of applicants were still in school, enrolled in grades ranging from 6th for the 1997 cohort to 8th or 9th for the 1993 cohort. Cohorts advance less than one grade per year because of repetition. The descriptive statistics also show that almost $90 \%$ of the applicants we interviewed started 6th grade in private school. This reflects the fact that eligibility for PACES vouchers was conditional on admission to a participating private school. Thus, most lottery losers went to private school anyway, at least for one year. On the other hand, only $63 \%$ of applicants were still in private school as of the survey date.

\section{B. Personal Characteristics and Voucher Status}

There is little evidence of any association between win/loss status and the individual characteristics measured in our data from Bogota, although winners and losers are less comparable in the 1993 Jamundi cohort. This can be seen in Table 2, which reports means and differences by win/loss status for all applicants in the study population, for sampled applicants, and for the sample of completed surveys. The sampling process began with lists showing applicant ID numbers, names, addresses, and phone numbers, separately for winners and losers. To obtain demographic characteristics for all applicants, whether surveyed or not, we imputed applicant age using ID numbers (which incorporate birthdays). We note, however, that our strategy

\footnotetext{
${ }^{7}$ The vast majority of non-responders were people we could not reach by telephone, either because they had moved or because the telephone number we had no longer worked. Roughly $3 \%$ of families contacted refused to answer. The only significant difference in response rates by win/loss status is for the Jamundi cohort. In what follows, we present results for the Bogota 1995 cohort and the combined cohorts separately. Complete follow-up is the holy grail of education research. Even careful evaluation studies using randomized and quasi-randomized designs (e.g., Rouse, 1998; Krueger and Whitmore, 2001) are based on samples with substantial loss to follow-up. Similarly, Howell et al (2000) report follow-up rates similar to ours for US voucher trials in three cities.
} 
of imputing ages is subject to error since $13 \%$ of applicants have invalid ID numbers as determined by the ID number control digit. We excluded observations in which the applicant was younger than 9 or older than 25 . In practice, this restriction affected only two observations. A second variable from the applicant record is gender. We used first names to assign sex for about $80 \%$ of the applicants. A final variable from the applicant record is a dummy for whether the record included a phone number.

Winners and losers have similar telephone access, age, and sex mix in the 1995 and 1997 Bogota data. As a further check on randomness, we compared win rates by school in those schools with more than 20 applicants to city averages in the Bogota data from 1995. No school had a win rate that differed significantly from the city average. In the Jamundi-93 sample, however, there are significant differences in average age and gender by win/loss status. Because the differences between winners and losers in the Jamundi lottery may indicate non-random assignment of vouchers, and because the 1997 Bogota cohort is too recent for a good reading on some outcomes, we present results from the Bogota-95 sample separately from the results for the pooled sample including all three cohorts.

\section{Impact on Scholarship Use, School Choice, and Schooling}

Our estimates of lottery effects are based on the following regression model:

$$
\mathrm{y}_{\mathrm{ic}}=\mathrm{X}_{\mathrm{i}}^{\prime} \beta_{0}+\alpha_{0} \mathrm{Z}_{\mathrm{i}}+\delta_{\mathrm{c}}+\varepsilon_{\mathrm{ic}},
$$

where $y_{i c}$ is the dependent variable for child i from application cohort c (defined by city and year); $X_{i}$ represents a vector of individual and survey characteristics like age, sex, and whether the survey was telephone or in-person; $Z_{\mathrm{i}}$ is an indicator for whether child i won the voucher lottery; and $\delta_{\mathrm{c}}$ is an applicant cohort effect to control for the fact that the probability of winning varied by city and year. The coefficient of interest is $\alpha_{0}$. We estimate (1) using three sets of control variables: "no controls", i.e., excluding the $\mathrm{X}_{\mathrm{i}}$ variables; "basic controls" including the $\mathrm{X}_{\mathrm{i}}$ variables; and "basic plus barrio controls" which includes the $\mathrm{X}_{\mathrm{i}}$ variables plus 19 neighborhood dummies in the Bogota-95 sample. ${ }^{8}$

\footnotetext{
${ }^{8}$ Neighborhoods in this case are large areas or districts.
} 


\section{A. Effects on Scholarship Use and School Choice}

We begin with a simple analysis of the effect of winning the lottery on private school scholarship receipt and the choice between public and private school. The most immediate effect of the lottery was to increase the likelihood of receiving a private school scholarship. This can be seen in the first row of Table 3, which shows that at the time of our survey, voucher winners were 51 percentage points more likely than losers to have been using some kind of scholarship (including non-PACES scholarships). Not all winners were using their PACES vouchers in the survey year. This is because $15 \%$ of winners were not in school at all, and another $16 \%$ were in public schools, and therefore ineligible for scholarships. Some lottery winners also lost their voucher after repeating a grade (7\%), while 5\% switched to non-participating private schools or failed to complete the paperwork for a transfer. Others attended schools that stopped accepting vouchers or lost their vouchers for unreported reasons. Just as not all winners were using a scholarship, some losers obtained scholarships from programs other than PACES and one loser was awarded a PACES voucher after re-applying the following year.

At the time of the survey, enrollment rates were .83 for losers and .85 for winners in the Bogota- 95 sample, an insignificant difference. The estimates in Table 3 also show that most PACES applicants entered $6^{\text {th }}$ grade in a private secondary school, and most finished $6^{\text {th }}$ grade whether or not they won a voucher. But lottery winners were 6-7 percentage points more likely than losers to have begun $6^{\text {th }}$ grade in private school, and 15-16 percentage points more likely to be in private school at the time of our survey. The effect of winning the PACES lottery on the probability of private school attendance was even larger in $7^{\text {th }}$ grade, probably because losers were more likely to have left private school by then.

These results suggest the decision between public and private school was sensitive to variation in the price of private school induced by the program, while the decision whether to attend school was not. ${ }^{9}$ This is consistent with a model in which those households most willing and able to pay for education attend private

\footnotetext{
${ }^{9}$ We can convert the private-school enrollment effects to an elasticity as follows. PACES vouchers reduced the marginal cost of private school attendance by about $50 \%$, while vouchers increased private school enrollment in $7^{\text {th }}$ grade by about $17 \%$. The implied elasticity of private enrollment with respect to marginal cost is therefore .34 .
} 
school; a middle group attends public school; and those least willing or able to pay do not attend at all. In this case, no one is on the private school/no school margin, and so small subsidies to private education do not directly increase overall enrollment. ${ }^{10}$ However, since many public schools in Colombia were turning away applicants due to overcrowding, PACES is likely to have opened up places in public school for other pupils by reducing public-school queuing.

\section{B. Effects on Schooling}

Lottery winners completed more schooling than losers, and were less likely to repeat grades. For example, lottery losers had completed 7.5 years of schooling at the time of our survey, but winners in the 1995 Bogota sample completed an additional .12-.16 years (.8 years in the full sample). As noted earlier, there was no statistically significant effect on enrollment. The effect on years of schooling and the lack of an effect on enrollment is primarily the result of a reduced probability of grade repetition for winners. This is reflected in a sharp increase in the likelihood lottery winners had finished $8^{\text {th }}$ grade as of the survey date, with a smaller impact on $7^{\text {th }}$ grade completion. In the Bogota-95 sample, over $20 \%$ of losers had repeated a grade since beginning $6^{\text {th }}$ grade, and almost $20 \%$ repeated $6^{\text {th }}$ grade. But the probability of grade repetition was reduced by 5-6 percentage points for lottery winners.

The estimates of $\alpha_{0}$ change little as the list of control variables changes, a result to be expected since the voucher lottery was random. The estimation results are also similar in the Bogota-95 and full samples, and are largely invariant to the inclusion of neighborhood effects. Estimates and standard errors for the Bogota 1995 sample also change little in models with school effects.

Separate results by sex, reported in Table 4, show moderately larger effects on educational attainment for girls, though the pattern of sex differences in the effects on private school enrollment are not clear cut. Results for the Bogota-95 sample show male lottery winners with an insignificant 0.12 more years of

${ }^{10} \mathrm{PACES}$ subsidies were initially large enough to cover the entire cost of private school, and may have shifted recipients from no school to private school when the program started. However, the voucher value was later eroded by inflation. 
schooling while female lottery winners obtained 0.14 years more of schooling, a statistically significant effect. Differences by sex are more pronounced in the full sample, with an insignificant 0.06 more years of schooling for boys, and a statistically significant 0.12 more years of schooling for girls. It should also be noted that while effects for boys are almost entirely due to grade repetition, the effects for girls appear to come from both reduced grade repetition and additional time spent in school. ${ }^{11}$

The greater probability of $8^{\text {th }}$ grade completion and lower repetition rates for lottery winners seem like desirable outcomes. In fact, high rates of grade repetition in Latin America are widely seen as symptomatic of poorly functioning public schools. ${ }^{12}$ But the interpretation of these effects is complicated by the fact that pupils who failed a grade were supposed to forfeit PACES vouchers. Private schools may therefore have had an incentive to promote pupils with vouchers even if their performance did not meet normal promotional standards. To explore this possibility, we look at effects on test scores and non-educational outcomes in the next section.

\section{Effects on Test Scores and Non-Education Outcomes}

\section{A. Effects on Test Scores}

We tested children from the 1995 applicant cohort in three Bogota neighborhoods. These neighborhoods were chosen because they had relatively large numbers of winners and losers, and because of the availability of suitable (and safe) testing sites. The tests were administered in 1999, approximately one year after our household survey and three years after the children applied for the program. The test sample was drawn from applicants for whom we had survey data. Participants were solicited by telephone, followed by hand delivery of letters describing the purpose of the test and inviting pupils to be tested. Those who failed to appear on the test day were invited again for a second testing, except at the last sitting. To encourage

\footnotetext{
${ }^{11}$ There is little evidence that the effect of winning the voucher varied with applicants' socioeconomic strata of residence or parents' education. However, estimates for subgroups are imprecise.

${ }^{12}$ For example, Psacharopolous and Velez (1993) and Harbison and Hanushek (1992) use repetition rates as a measure of school quality in Colombia and Brazil.
} 
participation, refreshments were provided at each site, and each test concluded with the raffle of a bicycle and other prizes. Pupils were also given 5 or 10 thousand pesos (US $\$ 3.23$ or $\$ 6.45$ ) to cover travel costs. The invitation letter noted the offer of refreshments, travel reimbursement, and raffle. See the data appendix for additional details on the testing.

Our evaluation used La Prueba de Realizacion, a grade-specific multiple-choice achievement test for native Spanish speakers, published by Riverside. We administered only the mathematics, reading, and writing subtests, each taking about 30 minutes. This test was chosen because Colombian educators participated in test development and the test had been used previously in Colombia (Cole et al, 1993). The appendix to our working paper (Angrist et al, 2001) compares test results from the Hispanic-American test-norming populations for grades 9 and 10 with the results from our test. Colombian 9th graders in our sample scored lower than American pupils in mathematics, but they had reading skills slightly better than American 10th graders. The average Colombian writing score was close to the average score for American 10th graders.

\section{The Test Sample}

Of the 1,176 Bogota 1995 applicants surveyed, 473 were invited for testing. Statistics for pupils invited and tested appear in the last column of Table 1 . Of the 473 invited, 283 were tested, an overall response rate of about $60 \%$. The test-response rate is about $5 \%$ higher for winners, but the difference in response rates by voucher status is not statistically significant. The personal characteristics of those tested are generally similar to those of the full Bogota 95 sample. Also encouraging is the fact that, conditional on taking the test, there is little evidence of differences in personal characteristics between voucher winners and losers. This comparison can be seen in the last column of Table 2 .

\section{Test results}

Table 5 reports estimates of the effect of winning the voucher lottery on test scores. Columns 1 and 
2 of Table 5 show results from models with and without covariates. ${ }^{13}$ Columns 3 and 4 present the results of estimating a single voucher coefficient for stacked subject results, in models with a pupil random effect. That is, we estimated:

$$
\mathrm{y}_{\mathrm{is}}=\mathrm{X}_{\mathrm{i}}^{\prime} \beta_{0}+\alpha_{0} \mathrm{Z}_{\mathrm{i}}+\delta_{\mathrm{i}}+\varepsilon_{\mathrm{is}}
$$

where $\mathrm{y}_{\mathrm{is}}$ is pupil i's score in subject $\mathrm{s}$, and $\delta_{\mathrm{i}}$ is a random effect used to adjust standard errors for the fact that there is likely to be within-pupil correlation across subjects. Note that test score results are reported in standard deviation units.

Lottery winners scored just over . 2 standard deviations more than lottery losers, though this difference is (not surprisingly, given the small test sample) only marginally significant. According to US norms for $L a$ Prueba, 2/10 of a standard deviation is roughly the score gain associated with one additional school year (Cole et al, 1993). This effect should probably therefore be seen as large, since subjects were tested three years after applying to the program. Lottery winners also scored higher on all subtests, though the only significant difference is for reading scores $(t=1.8)$. The results for the stacked subjects, reported in columns 3 and 4 , also show marginally significantly higher scores for lottery winners, with the largest effects for models that stack math and reading scores only.

Models estimated separately for boys and girls generate larger and more precise effects for girls than boys. For example, the estimated effect on total points for girls, reported in column 2 of Panel B for models with covariates, is $.26($ s.e. $=.13)$. The corresponding estimate for boys, reported in Panel C, is .17 (s.e.=.19). The finding of a stronger effect on girls echoes some of the survey results.

Earlier we noted that reduced grade repetition among lottery winners could theoretically have been caused by a reduction in promotion standards for lottery winners, as well as by increased learning or a change in school quality. Comparing the test scores of winners and losers who were promoted provides evidence that the grade repetition results are not due solely to schools' lowering the bar for promotion of winners. If

\footnotetext{
${ }^{13}$ The results in column 1 and 3 are from models that include site dummies only. The results in columns 2 and 4 are from models that include controls for age, sex, parents' schooling, strata of residence, type of interview, and survey form.
} 
the program itself did not affect achievement, but did lead schools to relax promotions standards for winners, then average test scores for lottery winners who were promoted should be lower than average test scores for lottery losers who were promoted. ${ }^{14}$ In fact, the composite test scores of winners who were promoted are about .14 standard deviations greater than the scores of promoted losers, although the difference is not significant.

Another possible channel through which the program could have reduced grade repetition is increased effort by voucher recipients in order to avoid failing a grade and losing their vouchers. In this scenario, the program would have been just as successful if it had made payment to students conditional on satisfactory academic performance, with no element of school choice. This would imply that the primary incentive effect should be on those who are near the margin for passing on to the next grade. However, quantile regression estimates (not reported here) suggest that the increase in test scores is not confined to low quantiles of the test score distribution. For reading and writing, there is no strong pattern of differential effects across quantiles, while for math, the effects are, if anything, larger at the top of the distribution. Standard errors for these estimate are, of course, large, given the small sample.

\section{B. Other Outcomes}

Table 6 reports estimates of the effect of winning the lottery on non-educational outcomes. Approximately $1.6 \%$ of lottery losers from Bogota were married or living with a companion, a low proportion consistent with the fact that the average age of survey respondents was about 15 . Since this outcome is rare, we estimated probit models as well as linear probability models.

Both probit marginal effects and OLS estimates suggest that marriage and cohabitation were reduced

\footnotetext{
${ }^{14}$ Suppose schools promote if a random variable $x$, representing the school's internal assessment of the student, is greater than a cutoff $c$, which takes on two values, $c_{W}$ for winners and $c_{L}$ for losers. Suppose $c_{W}<c_{L}$, but test scores, $\mathrm{T}$, and the variable $x$ are unaffected by winning the lottery. Then the expected test score for lottery losers who are promoted is $\mathrm{E}\left(\mathrm{T} \mid x>c_{L}\right)$. The expected score for winners will be a weighted average of this and $\mathrm{E}\left(\mathrm{T} \mid c_{W}<x<c_{L}\right)$. Average scores for promoted losers will therefore exceed average scores for promoted winners as long as $\mathrm{E}(\mathrm{T} \mid x)$ is increasing in $x$.
} 
for lottery winners, a marginally significant effect. There is some evidence from the pooled sample that lottery winners were less likely to be working than losers, with the largest effects in Bogota. There is also a significant difference in hours worked. In particular, lottery winners worked 1.2 fewer hours per week than losers. This effect is larger and more precisely estimated for girls. The reduction in work may be due to income effects for the household, the greater time demands of private school relative to public school, or increased incentives for lottery winners to spend time studying so as to avoid failing a grade and losing the PACES voucher.

\section{Instrumental Variables Estimates of Scholarship Effects}

The analysis so far focuses on reduced form effects of winning the lottery. In the discussion of Table 3, however, we noted that some lottery losers were awarded other scholarships, while some winners failed to use or retain their PACES scholarships. This section reports 2SLS estimates of the effect of ever receiving any scholarship using voucher win/loss status as an instrumental variable (IV). While only $6 \%$ of lottery losers used a scholarship at the time of the survey, $24 \%$ had used a scholarship at some point. In contrast, $90 \%$ of winners used a scholarship at some time. The 2SLS estimates based on this difference are necessarily larger than the reduced form effects of winning the lottery since winning the lottery is only imperfectly correlated with receiving a scholarship.

The assumption that a scholarship use dummy satisfies an exclusion restriction in an instrumental variables (IV) setup motivates 2 SLS estimation of the equation:

$$
\mathrm{y}_{\mathrm{i}}=\mathrm{X}_{\mathrm{i}}^{\prime} \beta_{1}+\alpha_{1} \mathrm{~s}_{\mathrm{i}}+\xi_{\mathrm{i}}
$$

where $\mathrm{s}_{\mathrm{i}}$ is a dummy for scholarship use, and $\mathrm{X}_{\mathrm{i}}$ is the vector of "basic controls" used in previous tables. The associated first-stage relationship using $Z_{\mathrm{i}}$ as an instrument is

$$
\mathrm{s}_{\mathrm{i}}=\mathrm{X}_{\mathrm{i}}{ }^{\prime} \gamma+\pi \mathrm{Z}_{\mathrm{i}}+\eta_{\mathrm{i}}
$$

The estimate of $\pi$ is about .66 (s.e. $=.021$ ), so the second-stage estimates can be expected to be about $50 \%$ larger than the corresponding reduced form estimates. The interpretation of $\alpha_{1}$ in this case is as an 
approximate effect of treatment on the subset of scholarship users who would not have used a scholarship without PACES (Imbens and Angrist, 1994). ${ }^{15}$

The 2SLS estimate of the effect of scholarship use on highest grade completed is about .2 in the Bogota-95 sample and .13 in the full sample. These estimates are reported in Table 7. 2SLS estimates of voucher effects on the probability of finishing eighth grade are $13-15$ percentage points, nearly a $25 \%$ increase in completion rates. This seems to be in the ballpark of Dynarski's (2001) estimated completion elasticities with respect to US financial aid for college students, though obviously not directly comparable. Another interesting result is the 2SLS estimate of the effect on test scores, .29, somewhat smaller than the corresponding OLS estimate. The 2SLS estimates are likely to be more useful for predicting the impact of scholarship programs on new scholarship recipients than are the reduced form effects, which are diluted by take-up rates less than one and the availability of alternative financing.

\section{Impact on Household and Government Expenditure}

This section discusses the impact of the program on household and government budgets. We begin by showing that approximately $70 \%$ of voucher funds flowed to increased education expenditures, with the remainder going to educational spending that households would have made without the voucher. Taking into account the reduction in work by lottery winners suggests that winning the lottery induced households to devote more net resources to education. The higher fees paid by voucher winners are due primarily to winners' greater likelihood of attending private school. However, there is also some evidence that applicants who would have attended private schools anyway traded up to more expensive private schools in response to winning the voucher. Since the voucher did not reduce the cost of private school at the margin, this result weighs against the simplest models of education as human capital investment without credit constraints. The

\footnotetext{
${ }^{15}$ At first blush, private school attendance might appear to be the appropriate endogenous regressor for a 2SLS setup. But this seems unlikely to satisfy the required exclusion restriction since increased effort and increased school quality probably also mediate the effects of the voucher. Consistent with this, in practice, 2SLS estimates treating private school attendance as an endogenous regressor generate estimates that are implausibly large.
} 
results in section B suggest that it cost the government about $\$ 24$ more per lottery winner to provide school places through PACES than through the public system. Finally, section $\mathrm{C}$ aggregates the impact on households, schools, and the government budget, arguing that the total social costs of providing additional school places through the PACES voucher system were small, and therefore dwarfed by the benefits of the program to participants. The analysis in this section uses data for the 1995 Bogota applicant cohort only.

\section{A. Impact on Household Educational Expenditure}

Three years after the 1995 lottery in Bogota, about 55\% of winners and 5\% of losers were still receiving scholarships (a result from Table 3 repeated in the first row of Table 8 for the sample of observations with usable fee data). In this sample, $53 \%$ of losers were still in private school in the survey year, with the private school enrollment rate $15.2 \%$ higher for winners after control for covariates.

Among applicants to the Bogota 95 lottery, winners received an average of \$74 more in scholarship aid than losers, result reported in the fourth row of Table 8. Conditional on receiving a scholarship, scholarship amounts were similar for winners and losers, at roughly $\$ 200$. The estimates in Table 8 also show gross matriculation and tuition fees were $\$ 52$ greater for lottery winners than losers. Thus, the 1998 voucher expenditures of $\$ 74$ per winner caused an increase of $\$ 52$ in gross fees for winners, about $70 \%$ of the extra amount received by winners on average. The remaining $\$ 22$ of voucher funds presumably increased noneducational expenditures by lottery winners. ${ }^{16}$

Aside from paying for school fees, households bear the opportunity cost of the effort students devote to education. The estimates for non-educational outcomes in Table 6 suggest lottery winners spent 1.2 fewer hours working each week. According to our survey data, the average hourly wage was 71 cents. ${ }^{17}$ Assuming

\footnotetext{
${ }^{16}$ The estimated displacement of private expenditure is even lower when a more comprehensive expenditure measure is used. Lottery winners report an estimated $\$ 84$ more in comprehensive scholarship assistance (i.e., including expenditure on uniforms and textbooks) and an extra $\$ 74$ more in comprehensive educational expenditure.

${ }^{17}$ Conditional on working, the average daily wage in our sample is $\$ 5.71$. We estimate the hourly wage assuming a 7 hour work day.
} 
that students work 48 weeks per year, this reduction corresponds to an opportunity cost of $1.2 \times \$ .71 \times 48$ weeks, approximately $\$ 41$. Combining the increase of $\$ 52$ in expenditures on fees and the $\$ 41$ of lost earnings, we estimate that PACES lottery winners devoted $\$ 93$ more to education than losers in the survey year, or $126 \%$ of the $\$ 74$ in extra scholarship assistance they received.

\section{Disaggregating Effects on Fees}

While winning households spent about $\$ 52$ more on school fees, on average, this average conceals important heterogeneity. Since vouchers covered only part of the cost of private school, families with children who were induced to switch to private school increased their educational expenditure sharply. However, most of the applicants who lost the lottery started private school in $6^{\text {th }}$ grade anyway, and over half were still in private school in the survey year. So most vouchers were received by applicants who would have attended private school without the vouchers.

Simple models of education as human capital investment with perfect credit markets suggest that since PACES vouchers were worth only $\$ 190$ per year, while most private schools cost over $\$ 300$ per year, vouchers were infra-marginal. In other words, vouchers were not large enough to have caused households to increase educational spending by choosing a more expensive private school. ${ }^{18}$ On the other hand, winning the voucher could have led households to choose more expensive private schools if educational spending is limited by credit constraints or if education has consumption value as well as investment value.

In a non-causal, purely accounting sense, the $\$ 52$ of increased expenditure by winners on school fees can be decomposed into the effects of increased private school enrollment, and a switch to more expensive private schools by winners. Let $\mathrm{Z}$ be a dummy for lottery win/loss status as before, except we now drop " $\mathrm{i}$ " subscripts to simplify notation. Also, let R denote type of school attended ( 1 for private, 0 for public) and let F denote education expenditure. Gross school fees conditional on lottery win/loss status (i.e, fees paid by

\footnotetext{
${ }^{18}$ To see this, note that if education is pure human capital investment, people choose schools so that a school costing one dollar more generates exactly one more dollar of present discounted earnings. For people who would in any case have attended a school costing more than $\$ 190$, the voucher does not affect this first order condition.
} 
pupils without subtracting voucher amounts) are equal to

$$
E[F \mid Z]=E[F \mid Z, R=1] P[R=1 \mid Z]+E[F \mid Z, R=0] P[R=0 \mid Z]
$$

The overall change in fees is a linear combination of changes in public/private enrollment and changes in fees charged by school type. We can simplify the fee contrast between winners and losers using the fact that public school fees changed little and overall school enrollment was also affected little, so that $P[R=1 \mid Z=1]-P[R=1 \mid$ $\mathrm{Z}=0] \approx-\{\mathrm{P}[\mathrm{R}=0 \mid \mathrm{Z}=1]-\mathrm{P}[\mathrm{R}=0 \mid \mathrm{Z}=0]\}$. Then we have the accounting relationship:

$$
\begin{aligned}
& \mathrm{E}[\mathrm{F} \mid \mathrm{Z}=1]-\mathrm{E}[\mathrm{F} \mid \mathrm{Z}=0] \\
& \begin{aligned}
=\{\mathrm{E}[\mathrm{F} \mid \mathrm{Z}=1, \mathrm{R}=1]-\mathrm{E}[\mathrm{F} \mid \mathrm{Z}=1, \mathrm{R}=0]\}\{\mathrm{P}[\mathrm{R}=1 \mid \mathrm{Z}=1]-\mathrm{P}[\mathrm{R}=1 \mid \mathrm{Z}=0]\} \\
\\
+\mathrm{P}[\mathrm{R}=1 \mid \mathrm{Z}=0]\{\mathrm{E}[\mathrm{F} \mid \mathrm{Z}=1, \mathrm{R}=1]-\mathrm{E}[\mathrm{F} \mid \mathrm{Z}=0, \mathrm{R}=1]\} .
\end{aligned}
\end{aligned}
$$

In words, the overall fee increase is caused by the private-public fee difference for winners, times privateschool enrollment effects of the program, plus the win/loss contrast in fees for private-school pupils. ${ }^{19}$ The right hand side components of (5) are as follows:

$$
\begin{aligned}
& P[R=1 \mid Z=1]-P[R=1 \mid Z=0]=.15 \\
& E[F \mid Z=1, R=1]-E[F \mid Z=1, R=0]=343-58=285 \\
& E[F \mid Z=1, R=1]-E[F \mid Z=0, R=1]=11 \\
& P[R=1 \mid Z=0]=.53 .
\end{aligned}
$$

This implies a total effect of $\$ 49$, which is less than $\$ 52$ because of the approximation used to simplify (5), with $\$ 43$ due to school switching. Thus, in an accounting sense, the bulk of the change in household expenditure can be attributed to increased private school enrollment. However, for reasons discussed below, this decomposition provides an incomplete picture of the causal effect of the program on the fee distribution.

Causal effects on fees for families who would have sent their children to private school anyway are difficult to measure since we do not know who these families are. Simply comparing fees by win/loss status

\footnotetext{
${ }^{19}$ Without simplification the comparison is

$\mathrm{E}[\mathrm{F} \mid \mathrm{Z}=1]-\mathrm{E}[\mathrm{F} \mid \mathrm{Z}=0]$

$=\mathrm{P}[\mathrm{R}=1 \mid \mathrm{Z}=0]\{\mathrm{E}[\mathrm{F} \mid \mathrm{Z}=1, \mathrm{R}=1]-\mathrm{E}[\mathrm{F} \mid \mathrm{Z}=0, \mathrm{R}=1]\}+\mathrm{E}[\mathrm{F} \mid \mathrm{Z}=1, \mathrm{R}=1]\{\mathrm{P}[\mathrm{R}=1 \mid \mathrm{Z}=1]-\mathrm{P}[\mathrm{R}=1 \mid \mathrm{Z}=0]\}$

$+\mathrm{P}[\mathrm{R}=0 \mid \mathrm{Z}=0]\{\mathrm{E}[\mathrm{F} \mid \mathrm{Z}=1, \mathrm{R}=0]-\mathrm{E}[\mathrm{F} \mid \mathrm{Z}=0, \mathrm{R}=0]\}+\mathrm{E}[\mathrm{F} \mid \mathrm{Z}=1, \mathrm{R}=0]\{\mathrm{P}[\mathrm{R}=0 \mid \mathrm{Z}=1]-\mathrm{P}[\mathrm{R}=0 \mid \mathrm{Z}=0]\}$.
} 
conditional on private school attendance (the second term in (5), above) leads to a biased estimate that is almost certainly too low. To see this, let $\mathrm{F}_{0}$ be the public or private fee a pupil would pay if he or she loses the lottery and let $F_{1}$ be the public or private fee he or she would pay if he or she wins, and let $R_{0}$ and $R_{1}$ denote private school attendance if a pupil loses or wins the lottery respectively. Similarly, let $\mathrm{f}_{0}$ be the private school fee a pupil would pay if he or she loses the lottery and let $f_{1}$ be the private school fee a pupil would pay if he or she wins. Thus $\mathrm{f}_{0}=\mathrm{F}_{0} \times \mathrm{R}_{0}$ and $\mathrm{f}_{1}=\mathrm{F}_{1} \times \mathrm{R}_{1}$. We imagine that these variables are defined for every pupil, though in practice, we can only observe $F_{0}, R_{0}$, and $f_{0}$ for losers and $F_{1}, R_{1}$, and $f_{1}$ for winners. $E\left[f_{1}\right.$ $\left.f_{0} \mid f_{0}>0\right]$ is the effect on fees for those who would attend private school even if they were to lose the lottery. The observed contrast in fees for private school pupils can be written as follows

$$
E[F \mid Z=1, R=1]-E[F \mid Z=0, R=1]=E\left[f_{1}-f_{0} \mid f_{0}>0\right]+\left\{E\left[f_{1} \mid f_{1}>0\right]-E\left[f_{1} \mid f_{0}>0\right]\right\}
$$

The term in curly brackets comes from selection bias in the conditional-on-positive contrast. Under mild assumptions, this term is negative. ${ }^{20}$ Assuming, as seems likely, that $\mathrm{f}_{1} \geq \mathrm{f}_{0}$, the left hand side therefore is a lower bound on the causal effect, $E\left[f_{1}-f_{0} \mid f_{0}>0\right]$.

The parameter $E\left[f_{1}-f_{0} \mid f_{0}>0\right]$ is not identified without further assumptions (see, e.g., Chamberlain, 1986), though the previous discussion suggests we can treat the observed contrast in fees for private school students as a lower bound. Under mild assumptions, we can obtain a reasonably tight upper bound on this and a related family of parameters: $E\left[f_{1}-f_{0} \mid f_{0}>m_{0}(\theta)\right]$ where $m_{0}(\theta)$ is the $\theta$-quantile of the losers' fee distribution. By choosing $\mathrm{m}_{0}(\theta)=0$, we bound $E\left[f_{1}-f_{0} \mid f_{0}>0\right.$, while picking points at higher quantiles, we measure the effect on those who would have spent more on private schooling in the absence of the lottery. For example, we can bound the effect of winning the lottery on private school fees for those who would have

\footnotetext{
${ }^{20}$ This is easy to show in a model where $\mathrm{f}_{1}=\mathrm{h}\left(\mathrm{f}_{0}\right)$ for any increasing transformation. More generally, winners who attend private school only if they win probably attend cheaper private schools than those who attend regardless in a variety of plausible models. Suppose, for example, that school quality complements ability and higher quality schools are more expensive. Then low-ability children attend public schools if they lose the lottery and attend cheap private schools if they win the lottery, while high-ability children attend expensive private schools whether or not they win a voucher. Alternatively, consider a model with credit constraints in which the poor attend public school; the rich attend private school; and the very rich attend expensive private schools. Then lottery winners who would have attended public school if they lost the lottery will attend cheaper schools than lottery winners who would have attended private school even if they lost.
} 
spent more than the voucher amount $(\$ 190)$ on private school fees in the absence of the lottery. This result is stated formally below:

Proposition. Suppose that $\mathrm{F}_{1} \geq \mathrm{F}_{0}$. Let $\mathrm{m}_{0}(\theta)$ be the $\theta$ quantile of the distribution $\mathrm{F}$ for losers, with $\mathrm{m}_{1}(\theta)$ defined similarly for winners. Then

$$
\mathrm{E}\left[\mathrm{f}_{1}-\mathrm{f}_{0} \mid \mathrm{f}_{0}>\mathrm{m}_{0}(\theta)\right] \leq\left\{\mathrm{E}\left[\mathrm{F} \mid \mathrm{Z}=1, \mathrm{~F}>\mathrm{m}_{1}(\theta)\right]-\mathrm{E}\left[\mathrm{F} \mid \mathrm{Z}=0, \mathrm{~F}>\mathrm{m}_{0}(\theta)\right]\right\} / \mathrm{P}\left[\mathrm{R}=1 \mid \mathrm{Z}=0, \mathrm{~F}>\mathrm{m}_{0}(\theta)\right]
$$

Proof. Define $\mathrm{F}_{\mathrm{M}}=\mathrm{F}_{0} 1\left(\mathrm{~F}_{0} \leq \mathrm{m}_{0}(\theta)\right)+\mathrm{F}_{0} 1\left(\mathrm{~F}_{0}>\mathrm{m}_{0}(\theta), \mathrm{R}_{0}=0\right)+\mathrm{F}_{1} 1\left(\mathrm{~F}_{0}>\mathrm{m}_{0}(\theta), \mathrm{R}_{0}=1\right)$. Note that $\mathrm{F}_{\mathrm{M}}=\mathrm{F}_{1}$ for households above the quantile who would have attended private schools anyway. Otherwise, $\mathrm{F}_{\mathrm{M}}=\mathrm{F}_{0}$. So $\mathrm{F}_{1}$ $\geq \mathrm{F}_{\mathrm{M}} \geq \mathrm{F}_{0}$. Let $\mathrm{p}_{\theta}=\mathrm{P}\left[\mathrm{R}_{0}=1 \mid \mathrm{F}_{0}>\mathrm{m}_{0}(\theta)\right]$. Then

$$
\begin{aligned}
& \mathrm{E}\left[\mathrm{F}_{\mathrm{M}} \mid \mathrm{F}_{0}>\mathrm{m}_{0}(\theta)\right]-\mathrm{E}\left[\mathrm{F}_{0} \mid \mathrm{F}_{0}>\mathrm{m}_{0}(\theta)\right] \\
& =\left\{\mathrm{p}_{\theta} \mathrm{E}\left[\mathrm{F}_{1} \mid \mathrm{F}_{0}>\mathrm{m}_{0}(\theta), \mathrm{R}_{0}=1\right]+\left(1-\mathrm{p}_{\theta}\right) \mathrm{E}\left[\mathrm{F}_{0} \mid \mathrm{F}_{0}>\mathrm{m}_{0}(\theta), \mathrm{R}_{0}=0\right]\right\}-\mathrm{E}\left[\mathrm{F}_{0} \mid \mathrm{F}_{0}>\mathrm{m}_{0}(\theta)\right] .
\end{aligned}
$$

Note that

$$
E\left[F_{0} \mid F_{0}>m_{0}(\theta)\right]=p_{\theta} E\left[F_{0} \mid F_{0}>m_{0}(\theta), R_{0}=1\right]+\left(1-p_{\theta}\right) E\left[F_{0} \mid F_{0}>m_{0}(\theta), R_{0}=0\right] .
$$

Therefore,

$$
E\left[F_{M} \mid F_{0}>m_{0}(\theta)\right]-E\left[F_{0} \mid F_{0}>m_{0}(\theta)\right]=p_{\theta} E\left[F_{1}-F_{0} \mid F_{0}>m_{0}(\theta), R_{0}=1\right]
$$

Since $\mathrm{f}_{0}=\mathrm{R}_{0} \mathrm{~F}_{0}$, this implies

$$
\left\{\mathrm{E}\left[\mathrm{F}_{\mathrm{M}} \mid \mathrm{F}_{0}>\mathrm{m}_{0}(\theta)\right]-\mathrm{E}\left[\mathrm{F}_{0} \mid \mathrm{F}_{0}>\mathrm{m}_{0}(\theta)\right\} / \mathrm{p}_{\theta}=\mathrm{E}\left[\mathrm{f}_{1}-\mathrm{f}_{0} \mid \mathrm{f}_{0}>\mathrm{m}_{0}(\theta)\right]\right.
$$

which is the quantity we seek to bound. Also, since $F_{1} \geq F_{M} \geq F_{0}$ for all applicants, $E\left[F_{1} \mid F_{1}>m_{1}(\theta)\right] \geq E\left[F_{1} \mid\right.$ $\left.\mathrm{F}_{0}>\mathrm{m}_{0}(\theta)\right] \geq \mathrm{E}\left[\mathrm{F}_{\mathrm{M}} \mid \mathrm{F}_{0}>\mathrm{m}_{0}(\theta)\right]$, and we have

$$
\mathrm{E}\left[\mathrm{F}_{1} \mid \mathrm{F}_{1}>\mathrm{m}_{1}(\theta)\right]-\mathrm{E}\left[\mathrm{F}_{0} \mid \mathrm{F}_{0}>\mathrm{m}_{0}(\theta)\right] \geq \mathrm{E}\left[\mathrm{F}_{\mathrm{M}} \mid \mathrm{F}_{0}>\mathrm{m}_{0}(\theta)\right]-\mathrm{E}\left[\mathrm{F}_{0} \mid \mathrm{F}_{0}>\mathrm{m}_{0}(\theta)\right] .
$$

By randomization, $E\left[F_{1} \mid F_{1}>m_{1}(\theta)\right]=E\left[F \mid Z=1, F>m_{1}(\theta)\right]$ and $E\left[F_{0} \mid F_{0}>m_{0}(\theta)\right]=E\left[F \mid Z=0, F>m_{0}(\theta)\right]$ and $\mathrm{p}_{\theta}=\mathrm{P}\left[\mathrm{R}=1 \mid \mathrm{Z}=0, \mathrm{~F}>\mathrm{m}_{0}(\theta)\right]$, which implies (6) and completes the proof.

To see why the upper bound works in the case where $\theta=0$, note that $\mathrm{E}\left(\mathrm{F}_{\mathrm{M}}-\mathrm{F}_{0}\right)$ is the average difference between winners' and losers' fees due to households who would have attended private schools in any case trading up to more expensive private schools. This is less than the observed difference in total fee payments by win/loss status, $\mathrm{E}\left(\mathrm{F}_{1}-\mathrm{F}_{0}\right)$. The econometric intuition for this result is that in parametric sample selection models, controlling for the probability of sample selection eliminates selection bias. Comparing winners and 
losers at the same quantiles equalizes the "probability of selection" if $F_{1}=h\left(F_{0}\right)$ for some monotone increasing transformation, $\mathrm{h}()$. In fact, with no public school fees, the bound is exact when $\mathrm{F}_{1}=\mathrm{h}\left(\mathrm{F}_{0}\right)$. More generally, dividing by $\mathrm{P}\left[\mathrm{R}=1 \mid \mathrm{Z}=0, \mathrm{~F}>\mathrm{m}_{0}(\theta)\right]$ corrects for the fact that some of those with positive fees were attending public school, and the bound applies even without a deterministic link between $\mathrm{F}_{0}$ and $\mathrm{F}_{1}$.

Estimates of (6) are reported in Table 9, along with a lower bound using the biased comparison for quantiles analogous to (6), i.e., $\left.\left.E[F \mid Z=1, R=1] F>m_{0}(\theta)\right]-E[F \mid Z=0, R=1] F>m_{0}(\theta)\right]$. As noted earlier, this is a plausible lower bound because of negative selection bias. Note also that any reasonable behavioral model would predict that a family that spent less than the voucher amount on private school without a voucher would spend more after the voucher. We therefore focus on bounding effects that are conditional on paying prevoucher fees equal to at least the voucher amount, roughly $\$ 190$.

Among losers paying at least $\$ 190$ in fees, the average fee was $\$ 371$. Almost all of these pupils were in private school (in fact, some reports of public school fees above $\$ 190$ are probably in error; others refer to a handful of elite public schools that charge significant fees). The lower bound on $E\left[f_{1}-f_{0} \mid f_{0}>190\right]$ is about $\$ 3$, but the upper bound is $\$ 38$. The voucher amount of $\$ 190$ is the .52 quantile of the fee distribution. Above this amount, the bounds are tighter. The estimated upper bounds above .6 range from $\$ 31$ to $\$ 48$, while the lower bounds range from $\$ 9$ to $\$ 28$. The lower bound estimates are not significantly different from zero at the $5 \%$ level. In some cases, however, the lower bounds are close to a $10 \%$ significance level, while the upper bounds allow for effects on the order of $10 \%$ of fee costs and $20 \%$ of the voucher value. Thus, it seems likely that winners in the upper half of the fee distribution spent 5-10\% more on private schools than they otherwise would have. This implies that the marginal propensity to spend voucher income on more expensive private schools was non-trivial, counter to a simple model of human capital investment without credit constraints.

\section{Price discrimination by private schools}

Another potential source of increased expenditure on fees by winners is price discrimination. There 
is little evidence that private schools discriminated by charging more to applicants with PACES scholarships. The easiest way for schools to price discriminate was to offer scholarships to those less likely to be able to afford education at the full price, i.e., applicants without PACES vouchers. In practice, however, we found little evidence of price discrimination. Our survey indicates that roughly $6 \%$ of losers in private school received a school scholarship, while 3\% of winners in private school received a school scholarship. This is a small and insignificant difference. Per lottery winner, i.e., without conditioning on attending private school, the difference is only about $1 \%$.

\section{B. Impact on the Government Budget}

The PACES program was established in part to expand secondary school enrollment without using the public system. We estimate that the program increased public educational expenditure by about $\$ 24$ per lottery winner, relative to the cost of accommodating these pupils in public school. As discussed in Section III, winners were no more likely than losers to attend school, but the program probably did expand overall school enrollment by freeing up places in public schools as lottery winners transferred to private schools.

To see where the $\$ 24$ figure comes from, note that the probability of attending public school, reported in Table 8 , fell by 0.14 for lottery winners. The average per-pupil cost of a public secondary school slot was about $\$ 350$, excluding implicit rental for school facilities. In the short run, the marginal cost of public school slots may differ from the average cost, but in the long run, it seems reasonable to assume marginal and average costs will be similar. Assuming the marginal cost of providing public school places equals the average cost, adding school spaces through PACES reduced long-run expenditure on public schools by $14 \%$ of $\$ 350$ or roughly $\$ 50$ per winner, so the extra public educational expenditure per lottery winner is about $\$ 74$ (to pupils) - $\$ 50$ (in reduced public school costs) $=\$ 24$. Moreover, allowing the marginal cost to differ from average cost by $\$ 100$ either way still leads to voucher program costs in the $10-40$ dollar range. 


\section{Overall Cost and Benefits}

The extra society-wide educational resource cost per lottery winner differs from the roughly $\$ 24$ of extra public education expenditure, since households used part of the voucher funds to offset education costs they would have incurred privately, and households lost income from their children's work. The average lottery winner received $\$ 74$ more than the average loser in scholarship assistance, but spent only $\$ 52$ more on gross school fees. Lottery winners earned $\$ 41$ less than losers through work. Winning households' net resource contribution was therefore $\$ 52$ (additional school fees) $+\$ 41$ (reduced earnings) - \$74 (voucher) $=\$ 19$. This implies that the society-wide additional educational resource cost per lottery winner was approximately $\$ 24$ (government) $+\$ 19$ (households) $=\$ 43$.

The comparison of costs and benefits should take account of the fact that three years of costs were incurred prior to our survey. The total cost of the program can therefore be estimated by multiplying the annual resource cost times the roughly 3 years winners received vouchers, for a total of about $3 \times 24=\$ 72$ in additional public educational expenditure and $3 \times \$ 43=\$ 129$ in total societal resource cost. Actual costs are probably somewhat higher, however, since voucher take-up rates declined over time, with $88 \%$ of winners having ever used a voucher, and only $49 \%$ using it in the survey year. Multiplying costs by $88 \% / 49 \%$ for the first and second years yields an upper bound on the three-year cost of the program of about $\$ 195$ using the \$43/year figure for social costs.

These costs are very likely small relative to the benefits for participants. Although lottery winners gave up current earnings, they completed an additional .12 to .16 grades and scored approximately .2 standard deviations higher on tests. Among US Hispanic students who took the same test, the difference in test scores between $7^{\text {th }}$ and $8^{\text {th }}$ graders, or between $8^{\text {th }}$ and $9^{\text {th }}$ graders, was also about .2 standard deviations, so the achievement gain from winning the lottery may be as large as that associated with a full year of schooling. Our estimates using a recent Colombian labor force survey show returns to schooling of about $10 \%$. If the gain from the program is only the economic return to an additional 0.12 years of schooling, the program raised winners' wages by $1.2 \%$ per year, whereas if it is equal to that from a full year of schooling it raised wages 
by $10 \%$. Annual earnings of parents in our sample were about $\$ 2,400$ per worker, and PACES applicants should be able to earn more, since the average parent had only 5.9 years of education while the average applicant had already completed 7.5 years and was still in school at the time of our survey. We therefore assume the expected earnings of applicants are $\$ 3000$. Thus, PACES seems very likely to raise lottery winners' wages by $\$ 36$ per year, and might raise wages by as much as $\$ 300$ per year if higher test scores have a grade-equivalent payoff. Discounted over applicants working lives, these benefits easily outweigh the social costs of the voucher program, which are probably no more than $\$ 195$.

A more complete cost-benefit analysis would take into account the program's effects on nonparticipants. Pupils left behind in public schools may have been hurt by the departure of motivated classmates for private schools, as argued by Hsieh and Urqiola (2001), or alternatively, public schools may have responded positively to increased competition, a possibility considered by Hoxby (2000) and Bettinger (2001b). Such general equilibrium effects cannot be assessed by comparing lottery winners and losers. But since the partial equilibrium cost-benefit analysis is clear-cut, and since only $15 \%$ of winners moved from public to private schools, any negative external effects on non-participants would have to have been extraordinarily large to outweigh program benefits.

\section{Summary and Conclusions}

Governments in many developing countries are increasingly willing to experiment with demand-side subsidies and public-private partnerships to meet basic education needs. The impact of these programs and policy innovations is an open question. Colombia's PACES program provides an unusual opportunity to assess the effect of demand-side education financing in a Latin American country where private schools educate a substantial fraction of pupils. The PACES program is of special interest because many vouchers were assigned by lottery, so program effects can be reliably assessed. Our results suggest that lottery winners benefitted from higher educational attainment, primarily as a consequence of reduced grade repetition, as well as from higher test scores and a lower probability of teen cohabitation or employment. Our estimates of the 
economic benefits to participants far exceed the estimated costs. Most of the results suggest PACES vouchers had a stronger effect on the education of girls than on the education of boys.

Our findings suggest that demand-side programs like PACES can be a cost-effective way to increase educational attainment and academic achievement, at least in countries like Colombia with a weak public school infrastructure and a well-developed private education sector. A number of channels could account for the impact of PACES vouchers. First, lottery winners were more likely to have attended participating private schools, and these schools may be better than public schools. Second, vouchers allowed some pupils who would have attended private schools anyway to attend more expensive schools. Finally, because voucher recipients who failed a grade risked losing vouchers, lottery winners had an incentive to devote more effort to school. The net effect is such that the benefit of voucher awards were more than enough to offset the costs. In work in progress, we are assessing longer term consequences of voucher receipt. Preliminary results indicate that the program increased secondary school completion rates, and that college-entrance test scores were higher for lottery winners than losers. These results also show test score increases in the upper tail of the test score distribution, suggesting the effects reflect greater learning by high-achieving pupils and are not due solely to greater incentives for PACES recipients to avoid grade repetition. 


\section{REFERENCES}

Angrist, Joshua. "Conditional Independence in Sample Selection Models." Economics Letters, February 1997, 54(2), 103-112.

Angrist, Joshua; Bettinger, Eric; Bloom, Erik; King, Elizabeth and Kremer, Michael, "Vouchers for Private Schooling in Colombia: Evidence from a Randomized Natural Experiment,"NBER Working Paper No. 8343, June 2001.

Behrman, Jere; Sengupta, Piyali and Todd, Petra. "Progressing through PROGRESA: An Impact Assessment of Mexico's School Subsidy Experiment." Draft, 2000.

Bellow, Rosemary and King, Elizabeth M. "Educating Women: Lessons from Experience." in King and Hill (eds.), Women's Education in Developing Countries: Barriers, Benefits, and Policy, 1993, Baltimore: Johns Hopkins Press.

Bettinger, Eric. "Do Private School Vouchers Affect Test Scores and Why? Evidence from a Private School Scholarship Program." Case Western Reserve, Department of Economics, January 2001a, mimeo.

Bettinger, Eric. "The Effect of Charter Schools on Charter Students and Public Schools." Case Western Reserve, Department of Economics, March 2001b, mimeo.

Calderon, Alberto. "Voucher Programs for Secondary Schools: The Colombian Experience." Human Capital Development and Operations Policy Working Paper, Washington, DC: The World Bank, 1996, (http://www.worldbank.org/education/economicsed/finance/demand/related/wp 00066.html).

Chamberlain, Gary. "Asymptotic Efficiency in Semi-Parametric Models with Censoring." Journal of Econometrics, July 1986, 32(2), 189-218.

Cole, Nancy S.; Trent, E. Roger and Wadell, Dena C. La Prueba Riverside de Realización en Español:Teacher's Guide and Technical Summary. Chicago: The Riverside Publishing Company, 1993.

Cox, Donald and Jimenez, Emmanuel. "The Effectiveness of Private and Public Schools: Evidence from Two Developing Countries.” Journal of Development Economics, November 1990, 34(9), 99-121.

DNP, Sistema de Indicadores Sociodemograficos para Colombia (SISD) 1980-1997 Boletin No. 21, p. 58, Bogota: Departmento Nacional de Planeacion, June 1999.

Dynarski, Susan M. "Does Aid Matter? Measuring the Effect of Student Aid on College Attendance and Completion,” John F. Kennedy School of Government, Faculty Research Working Paper RWP01-034, September 2001.

Evans, William N. and Schwab, Robert M. "Finishing High School and Starting College: Do Catholic Schools Make a Difference?"Quarterly Journal of Economics, November 1995, 110(4), 941-974.

Glewwe, Paul; Kremer, Michael and Moulin, Sylvie, "Textbooks and Test Scores: Evidence from a Prospective Evaluation in Kenya." Harvard University, mimeo, September 2000.

Green, Jay; Peterson, Paul and Du, Jiangtao. "The Effectiveness of School Choice in Milwaukee: A Secondary Analysis of Data from the Program's Evaluation." Harvard Program in Education Policy and Governance, August 1996, Occasional Paper 96-3.

Harbison, R.W. and Hanushek, Eric A. Educational Performance of the Poor: Lessons from Rural Northeast Brazil. New York: Oxford University Press, 1992.

Hoxby, Caroline M. "Does Competition Among Public Schools Benefit Students and Taxpayers." American Economic Review, December 2000, 90(5), 1209-1238.

Howell, William G.; Wolf, Patrick J.; Peterson, Paul E. and Campbell, David E. "Test-Score Effects of

School Vouchers in Dayton, New York, and Washington: Evidence from Randomized Field Trials.” Paper presented at the annual meeting of the American Political Science Association, Washington, D.C., September 2000.

Hsieh, Chang-Tai, Miguel Urquiola. "When Schools Compete, How Do They Compete? An Assessment of Chile's Nationwide School Voucher Program.” Working Paper, Princeton University, September 2001.

Imbens, Guido W. and Angrist, Joshua D. "Identification and Estimation of Local Average Treatment Effects.” Econometrica, March 1994, 62(2), 467-476. 
Jacoby, Hanan. "Borrowing Constraints and Progress Through School: Evidence from Peru." Review of Economics and Statistics, February 1994, 76(1), 151-160.

James, Estelle. "Why Do Different Countries Choose a Different Public-Private Mix of Educational Services." Journal of Human Resources, Summer 1993, 28(3), 571-592.

Jimenez, Emmanuel; Lockheed, Marlaine E. and Paqueo, Vicente. "The Relative Efficiency of Private and Public Schools in Developing Countries.” The World Bank Research Observer, July 1991, 6(2), 205 218.

King, Elizabeth; Orazem, Peter and Wolgemuth, Darin. "Central Mandates and Local Incentives: The Colombia Education Voucher Program." Working Paper No. 6, Series on Impact Evaluation of Education Reforms, Development Economics Research Group, The World Bank, February 1998.

King, Elizabeth; Rawlings, Laura; Gutierrez, Marybell; Pardo, Carlos and Torres, Carlos. "Colombia's Targeted Education Voucher Program: Features, Coverage and Participation.” Working Paper No. 3, Series on Impact Evaluation of Education Reforms, Development Economics Research Group, The World Bank, September, 1997.

Krueger, Alan and Whitmore, Diane. "The Effect of Attending a Small Class in the Early Grades on College-Test Taking and Middle School Test Results: Evidence from Project STAR." Economic Journal, January 2001, 111(468), 1-28.

Kugler, Adriana D. "The Impact of Firing Costs on Turnover and Unemployment: Evidence from the Colombian Labour Market Reform." International Tax and Public Finance, August 1999, 6(3), 389-410.

Morales-Cobo, Patricia. "Demand Subsidies: A Case Study of the PACES Voucher Program.” Universidad de los Andes, Economics Department, Bogota, 1993, Processed.

Myers, David; Peterson, Paul; Mayer, Daniel; Chou, Julia and Howell, William. "School Choice in New York City After Two Years: An Evaluation of the School Choice Scholarships Program.” Program on Education Policy and Governance, mimeo, August 2000.

Myers, David, Peterson, Paul, and Howell, William. "An Evaluation of the New York City: School Choice Scholarships Program: The First Year.” Harvard's PEPG Occasional Paper Series, 2000.

Neal, Derek, "The Effects of Catholic Secondary Schooling on Educational Achievement." Journal Labor Economics, Part 1 January 1997, 15(1), 98-123.

Patrinos, Harry A. and Ariasingham, David L. Decentralization of Education: Demand-Side Financing. Washington, DC: The World Bank, 1997.

Psacharopolous, George; Tan, J., and Jimenez, E. Financing Education in Developing Countries: An Exploration of Policy Options. Washington DC: The World Bank, 1986.

Psacharopolous, George, and Velez, Eduardo. "Educational Quality and Labor Market Outcomes: Evidence from Bogota, Colombia." Sociology of Education, April 1993, 66(3), 130-145.

Rauch, James E. and Evans, Peter B. "Bureaucratic Structure and Bureaucratic Performance in Less Developed Countries.” Journal of Public Economics, January 2000, 75(1), 49-71.

Ribero, Rocío and Tenjo, Jaime. University de los Andes, Department of Economics Working Paper, 1997.

Rouse, Cecilia Elena. "Private School Vouchers and Student Achievement: An Evaluation of the Milwaukee Parental Choice Program.” Quarterly Journal of Economics, May 1998, 13(2), 553-602.

Sanchez, Fabio and Mendez, Jairo. "Por Que los Niños Pobres No Van A La Escuela? (Determinantes de la asistencia escolar en Colombia)." Mimeo, Departmento Nacional de Planeacion Republica de Colombia, 1995.

The PROBE Team, Public Report on Basic Education in India. Oxford: Oxford University Press, 1999.

US Department of Education, Office of Education Research and Improvement. The Condition of Education 1998, NCES 98-013, Washington, DC: USGPO, 1998.

The World Bank, World Development Report 1998/99. New York: Oxford University Press, 1999.

The World Bank, Research Department, Staff Appraisal Report: Colombia, Secondary Education Project, Human Resources Operations Division, Latin America and the Caribbean Region, Report No. 11834-CO, November 19, 1993. 
Table 1. Sample Design and Survey Response Data

\begin{tabular}{|c|c|c|c|c|c|}
\hline Variable & $\begin{array}{c}\text { Bogota } \\
95 \\
\end{array}$ & $\begin{array}{c}\text { Bogota } \\
97 \\
\end{array}$ & $\begin{array}{l}\text { Jamundi } \\
93 \\
\end{array}$ & $\begin{array}{l}\text { Combined } \\
\text { Sample } \\
\end{array}$ & $\begin{array}{c}\text { Test } \\
\text { Takers } \\
\end{array}$ \\
\hline \multicolumn{6}{|l|}{ A. Population } \\
\hline $\mathrm{N}$ & 4044 & 1770 & 342 & 6156 & -- \\
\hline$\%$ Awarded Vouchers & 58.8 & 84.7 & 50.0 & 65.8 & -- \\
\hline \multicolumn{6}{|l|}{ B. Attempted Interviews } \\
\hline $\mathrm{N}$ & 2249 & 457 & 279 & 2985 & 473 \\
\hline$\%$ Awarded Vouchers & 50.0 & 51.6 & 50.2 & 50.3 & 53.9 \\
\hline Response Rate & .523 & .606 & .591 & .542 & .598 \\
\hline Winner Rate & .528 & .619 & .650 & .553 & .624 \\
\hline Loser Rate & .518 & .593 & .532 & .531 & .571 \\
\hline \multicolumn{6}{|l|}{ C. Completed Interviews } \\
\hline $\mathrm{N}$ & 1176 & 277 & 165 & 1618 & 283 \\
\hline$\%$ Awarded Vouchers & 50.4 & 52.7 & 55.2 & 51.3 & 55.6 \\
\hline Household Visit & .054 & .004 & .782 & .120 & .093 \\
\hline $\begin{array}{l}\text { Age at time of } \\
\text { Application }\end{array}$ & $\begin{array}{l}12.6 \\
(1.3)\end{array}$ & $\begin{array}{l}12.4 \\
(1.4)\end{array}$ & $\begin{array}{l}12.5 \\
(1.9)\end{array}$ & $\begin{array}{l}12.6 \\
(1.4)\end{array}$ & $\begin{array}{l}12.6 \\
(1.2)\end{array}$ \\
\hline $\begin{array}{l}\text { Age on Survey Date } \\
\text { (from Survey Data) }\end{array}$ & $\begin{array}{l}15.0 \\
(1.3)\end{array}$ & $\begin{array}{l}13.1 \\
(1.4)\end{array}$ & $\begin{array}{l}16.9 \\
(1.5)\end{array}$ & $\begin{array}{l}14.9 \\
(1.7)\end{array}$ & $\begin{array}{l}15.6 \\
(1.2)\end{array}$ \\
\hline Male & .510 & .495 & .424 & .499 & .511 \\
\hline Started $6^{\text {th }}$ in Private & .910 & .880 & .669 & .880 & .832 \\
\hline Started $7^{\text {th }}$ in Private & .763 & .731 & .626 & .744 & .731 \\
\hline $\begin{array}{l}\text { Currently in Private } \\
\text { School }\end{array}$ & .618 & .738 & .506 & .628 & .698 \\
\hline $\begin{array}{l}\text { Highest Grade } \\
\text { Completed }\end{array}$ & $\begin{array}{l}7.6 \\
(040)\end{array}$ & $\begin{array}{c}6.0 \\
(.480)\end{array}$ & $\begin{array}{c}8.6 \\
(1.1)\end{array}$ & $\begin{array}{l}7.4 \\
(11)\end{array}$ & $\begin{array}{c}7.7 \\
(.910)\end{array}$ \\
\hline Currently In School & .836 & .957 & .778 & .851 & .841 \\
\hline
\end{tabular}

Notes: Standard Deviations for non-binary variables are shown in parentheses. Sample sizes may differ across rows. Data are from 1998 household surveys. "Age at time of Application" is imputed from the National Identification number reported on the application. 
Table 2. Personal Characteristics and Voucher Status

\begin{tabular}{|c|c|c|c|c|c|c|c|c|c|c|}
\hline \multirow[b]{2}{*}{$\begin{array}{l}\text { Dependent } \\
\text { Variable }\end{array}$} & \multicolumn{2}{|c|}{ Bogota 95} & \multicolumn{2}{|c|}{ Bogota 97} & \multicolumn{2}{|c|}{ Jamundi 93} & \multicolumn{2}{|c|}{$\begin{array}{l}\text { Combined } \\
\text { Sample }\end{array}$} & \multicolumn{2}{|c|}{ Test Takers } \\
\hline & $\begin{array}{c}\text { Loser } \\
\text { Means } \\
(1)\end{array}$ & $\begin{array}{c}\text { Won } \\
\text { Voucher } \\
(2)\end{array}$ & $\begin{array}{c}\text { Loser } \\
\text { Means } \\
(3) \\
\end{array}$ & $\begin{array}{c}\text { Won } \\
\text { Voucher } \\
(4)\end{array}$ & $\begin{array}{c}\text { Loser } \\
\text { Means } \\
(5) \\
\end{array}$ & $\begin{array}{c}\text { Won } \\
\text { Voucher } \\
(6)\end{array}$ & $\begin{array}{l}\text { Loser } \\
\text { Means } \\
(7) \\
\end{array}$ & $\begin{array}{c}\text { Won } \\
\text { Voucher } \\
(8)\end{array}$ & $\begin{array}{c}\text { Loser } \\
\text { Means } \\
(9) \\
\end{array}$ & $\begin{array}{c}\text { Won } \\
\text { Voucher } \\
(10) \\
\end{array}$ \\
\hline \multicolumn{11}{|c|}{ A. Data from PACES Application } \\
\hline Has Phone & .882 & $\begin{array}{c}.009 \\
(.011)\end{array}$ & .828 & $\begin{array}{l}.029 \\
(.025)\end{array}$ & .301 & $\begin{array}{l}.068 \\
(.052)\end{array}$ & .825 & $\begin{array}{l}.017 \\
(.010)\end{array}$ & -- & -- \\
\hline $\begin{array}{l}\text { Age at time of } \\
\text { Application }\end{array}$ & $\begin{array}{l}12.7 \\
(1.3)\end{array}$ & $\begin{array}{l}-.086 \\
(.045)\end{array}$ & $\begin{array}{l}12.7 \\
(1.5)\end{array}$ & $\begin{array}{l}-.227 \\
(.102)\end{array}$ & $\begin{array}{l}12.7 \\
(1.5)\end{array}$ & $\begin{array}{l}-.383 \\
(.162)\end{array}$ & $\begin{array}{l}12.7 \\
(1.4)\end{array}$ & $\begin{array}{l}-.133 \\
(.040)\end{array}$ & -- & -- \\
\hline Male & .493 & $\begin{array}{l}.013 \\
(.017)\end{array}$ & .484 & $\begin{array}{l}.007 \\
(.044)\end{array}$ & .386 & $\begin{array}{l}.114 \\
(.055)\end{array}$ & .483 & $\begin{array}{l}.019 \\
(.015)\end{array}$ & -- & -- \\
\hline $\mathrm{N}$ & 1519 & 3661 & 256 & 1736 & 166 & 334 & 1941 & 5731 & -- & -- \\
\hline \multicolumn{11}{|c|}{$\begin{array}{l}\text { B. Data for All Attempted } \\
\text { Contacts }\end{array}$} \\
\hline Has Phone & 1 & -- & 1 & -- & .370 & $\begin{array}{l}.082 \\
(.059)\end{array}$ & .938 & $\begin{array}{l}.008 \\
(.006)\end{array}$ & -- & -- \\
\hline $\begin{array}{l}\text { Age at time of } \\
\text { Application }\end{array}$ & $\begin{array}{c}12.8 \\
(1.3)\end{array}$ & $\begin{array}{l}-.118 \\
(.060)\end{array}$ & $\begin{array}{l}12.6 \\
(1.5)\end{array}$ & $\begin{array}{l}-.193 \\
(.136)\end{array}$ & $\begin{array}{l}12.8 \\
(1.6)\end{array}$ & $\begin{array}{l}-.595 \\
(.183)\end{array}$ & $\begin{array}{l}12.7 \\
(1.4)\end{array}$ & $\begin{array}{l}-.177 \\
(.052)\end{array}$ & -- & -- \\
\hline Male & .500 & $\begin{array}{l}-.007 \\
(.022)\end{array}$ & .488 & $\begin{array}{l}-.020 \\
(.048)\end{array}$ & .372 & $\begin{array}{l}.102 \\
(.061)\end{array}$ & .486 & $\begin{array}{l}.001 \\
(.019)\end{array}$ & -- & -- \\
\hline $\mathrm{N}$ & 1035 & 2067 & 212 & 448 & 135 & 272 & 1382 & 2787 & -- & -- \\
\hline \multicolumn{11}{|l|}{ C. Survey Data } \\
\hline $\begin{array}{l}\text { Age at time of } \\
\text { Survey }\end{array}$ & $\begin{array}{l}15.0 \\
(1.4)\end{array}$ & $\begin{array}{l}-.013 \\
(.078)\end{array}$ & $\begin{array}{l}13.2 \\
(1.4)\end{array}$ & $\begin{array}{l}-.259 \\
(.171)\end{array}$ & $\begin{array}{l}17.2 \\
(1.4)\end{array}$ & $\begin{array}{l}-.375 \\
(.217)\end{array}$ & $\begin{array}{l}14.9 \\
(1.7)\end{array}$ & $\begin{array}{l}-.107 \\
(.068)\end{array}$ & $\begin{array}{l}14.9 \\
(1.4)\end{array}$ & $\begin{array}{l}-.160 \\
(.162)\end{array}$ \\
\hline Male & .501 & $\begin{array}{c}.004 \\
(.029)\end{array}$ & .527 & $\begin{array}{l}-.047 \\
(.061)\end{array}$ & .365 & $\begin{array}{l}.110 \\
(.077)\end{array}$ & .492 & $\begin{array}{l}.008 \\
(.025)\end{array}$ & .447 & $\begin{array}{l}.053 \\
(.060)\end{array}$ \\
\hline $\begin{array}{l}\text { Mother's } \\
\text { Highest } \\
\text { Grade } \\
\text { Completed }\end{array}$ & $\begin{array}{l}5.9 \\
(2.7)\end{array}$ & $\begin{array}{l}-.079 \\
(.166)\end{array}$ & $\begin{array}{l}5.9 \\
(2.7)\end{array}$ & $\begin{array}{c}.654 \\
(.371)\end{array}$ & $\begin{array}{c}4.4 \\
(2.7)\end{array}$ & $\begin{array}{c}1.46 \\
(.494)\end{array}$ & $\begin{array}{c}5.8 \\
(2.7)\end{array}$ & $\begin{array}{c}.183 \\
(.144)\end{array}$ & $\begin{array}{c}5.5 \\
(2.9)\end{array}$ & $\begin{array}{l}-.277 \\
(.351)\end{array}$ \\
\hline $\begin{array}{l}\text { Father's } \\
\text { Highest } \\
\text { Grade } \\
\text { Completed }\end{array}$ & $\begin{array}{c}5.9 \\
(2.9)\end{array}$ & $\begin{array}{l}-.431 \\
(.199)\end{array}$ & $\begin{array}{c}5.5 \\
(2.5)\end{array}$ & $\begin{array}{c}.929 \\
(.388)\end{array}$ & $\begin{array}{c}5.2 \\
(2.9)\end{array}$ & $\begin{array}{c}.737 \\
(.640)\end{array}$ & $\begin{array}{c}5.8 \\
(2.9)\end{array}$ & $\begin{array}{l}-.042 \\
(.170)\end{array}$ & $\begin{array}{c}4.0 \\
(3.3)\end{array}$ & $\begin{array}{l}-.171 \\
(.392)\end{array}$ \\
\hline Mother's Age & $\begin{array}{l}40.7 \\
(7.3)\end{array}$ & $\begin{array}{l}-.027 \\
(.426)\end{array}$ & $\begin{array}{l}38.7 \\
(6.6)\end{array}$ & $\begin{array}{l}-.146 \\
(.808)\end{array}$ & $\begin{array}{l}43.6 \\
(8.8)\end{array}$ & $\begin{array}{c}-.736 \\
(1.42)\end{array}$ & $\begin{array}{l}40.6 \\
(7.4)\end{array}$ & $\begin{array}{l}-.076 \\
(.362)\end{array}$ & $\begin{array}{l}40.3 \\
(6.6)\end{array}$ & $\begin{array}{c}.459 \\
(.811)\end{array}$ \\
\hline Father's Age & $\begin{array}{l}44.4 \\
(8.1)\end{array}$ & $\begin{array}{c}.567 \\
(.533)\end{array}$ & $\begin{array}{l}41.9 \\
(7.3)\end{array}$ & $\begin{array}{c}.265 \\
(.973)\end{array}$ & $\begin{array}{l}45.5 \\
(9.1)\end{array}$ & $\begin{array}{c}1.92 \\
(1.61)\end{array}$ & $\begin{array}{l}44.1 \\
(8.1)\end{array}$ & $\begin{array}{c}.537 \\
(.453)\end{array}$ & $\begin{array}{l}43.5 \\
(7.7)\end{array}$ & $\begin{array}{c}1.18 \\
(1.06)\end{array}$ \\
\hline $\begin{array}{l}\text { Father's Wage } \\
\text { (>2 Min } \\
\text { Wage) }\end{array}$ & .100 & $\begin{array}{c}.005 \\
(.021)\end{array}$ & .088 & $\begin{array}{l}-.008 \\
(.043)\end{array}$ & .133 & $\begin{array}{l}-.092 \\
(.056)\end{array}$ & .101 & $\begin{array}{c}-.003 \\
(.018)\end{array}$ & $\begin{array}{c}.052 \\
(.222)\end{array}$ & $\begin{array}{l}.083 \\
(.039)\end{array}$ \\
\hline $\mathrm{N}$ & 583 & 1176 & 131 & 277 & 74 & 165 & 788 & 1618 & 124 & 283 \\
\hline
\end{tabular}

Notes: The table reports voucher losers' means and the estimated effect of winning a voucher. Numbers in parentheses are standard deviations in columns of means and standard errors in columns of estimated voucher effects. Models used for the estimates in Panels A and B include control for city and year of application; those for Panel C add controls for type of survey and instrument, neighborhood of residence, and month of interview. Sample size varies by row. The maximum sample size is shown in each panel. The sample for the outcome "Age at time of Application" is restricted to applicants 925 years old. 
Table 3. Educational Outcomes and Voucher Status

\begin{tabular}{|c|c|c|c|c|c|c|}
\hline \multirow[b]{2}{*}{ Dependent Variable } & \multicolumn{4}{|c|}{ Bogota 95} & \multicolumn{2}{|c|}{ Combined Sample } \\
\hline & $\begin{array}{l}\text { Loser } \\
\text { Means }\end{array}$ & No Ctls & $\begin{array}{c}\text { Basic } \\
\text { Ctls }\end{array}$ & $\begin{array}{c}\text { Basic } \\
+19 \\
\text { Barrio } \\
\text { Ctls } \\
(4)\end{array}$ & $\begin{array}{l}\text { Basic } \\
\text { Ctls }\end{array}$ & $\begin{array}{c}\text { Basic }+19 \\
\text { Barrio } \\
\text { Ctls } \\
\text { (6) }\end{array}$ \\
\hline $\begin{array}{l}\text { Using any Scholarship } \\
\text { in Survey Year }\end{array}$ & $\begin{array}{l}.057 \\
(.232)\end{array}$ & $\begin{array}{l}.509 \\
(.023)\end{array}$ & $\begin{array}{l}.504 \\
(.023)\end{array}$ & $\begin{array}{l}.505 \\
(.023)\end{array}$ & $\begin{array}{l}.526 \\
(.019)\end{array}$ & $\begin{array}{l}.521 \\
(.019)\end{array}$ \\
\hline $\begin{array}{l}\text { Ever Used a } \\
\text { Scholarship }\end{array}$ & $\begin{array}{l}.243 \\
(.430)\end{array}$ & $\begin{array}{l}.672 \\
(.021)\end{array}$ & $\begin{array}{l}.663 \\
(.022)\end{array}$ & $\begin{array}{l}.662 \\
(.022)\end{array}$ & $\begin{array}{l}.636 \\
(.019)\end{array}$ & $\begin{array}{l}.635 \\
(.019)\end{array}$ \\
\hline Started $6^{\text {th }}$ in Private & $\begin{array}{l}.877 \\
(.328)\end{array}$ & $\begin{array}{l}.063 \\
(.017)\end{array}$ & $\begin{array}{c}.057 \\
(.017)\end{array}$ & $\begin{array}{l}.058 \\
(.017)\end{array}$ & $\begin{array}{l}.066 \\
(.016)\end{array}$ & $\begin{array}{l}.067 \\
(.016)\end{array}$ \\
\hline Started $7^{\text {th }}$ in Private & $\begin{array}{c}.673 \\
(.470)\end{array}$ & $\begin{array}{c}.174 \\
(.025)\end{array}$ & $\begin{array}{c}.168 \\
(.025)\end{array}$ & $\begin{array}{c}.171 \\
(.024)\end{array}$ & $\begin{array}{c}.170 \\
(.021)\end{array}$ & $\begin{array}{c}.173 \\
(.021)\end{array}$ \\
\hline $\begin{array}{l}\text { Currently In Private } \\
\text { School }\end{array}$ & $\begin{array}{l}.539 \\
(.499)\end{array}$ & $\begin{array}{l}.160 \\
(.028)\end{array}$ & $\begin{array}{l}.153 \\
(.027)\end{array}$ & $\begin{array}{l}.156 \\
(.027)\end{array}$ & $\begin{array}{l}.152 \\
(.023)\end{array}$ & $\begin{array}{l}.154 \\
(.023)\end{array}$ \\
\hline $\begin{array}{l}\text { Highest Grade } \\
\text { Completed }\end{array}$ & $\begin{array}{l}7.5 \\
(.960)\end{array}$ & $\begin{array}{l}.164 \\
(.053)\end{array}$ & $\begin{array}{l}.130 \\
(.051)\end{array}$ & $\begin{array}{l}.120 \\
(.051)\end{array}$ & $\begin{array}{l}.085 \\
(.041)\end{array}$ & $\begin{array}{l}.078 \\
(.041)\end{array}$ \\
\hline Currently In School & $\begin{array}{l}.831 \\
(.375)\end{array}$ & $\begin{array}{l}.019 \\
(.022)\end{array}$ & $\begin{array}{l}.007 \\
(.020)\end{array}$ & $\begin{array}{l}.007 \\
(.020)\end{array}$ & $\begin{array}{l}-.002 \\
(.016)\end{array}$ & $\begin{array}{l}-.002 \\
(.016)\end{array}$ \\
\hline Finished $6^{\text {th }}$ Grade & $\begin{array}{l}.943 \\
(.232)\end{array}$ & $\begin{array}{l}.026 \\
(.012)\end{array}$ & $\begin{array}{c}.023 \\
(.012)\end{array}$ & $\begin{array}{l}.021 \\
(.011)\end{array}$ & $\begin{array}{l}.014 \\
(.011)\end{array}$ & $\begin{array}{l}.012 \\
(.010)\end{array}$ \\
\hline $\begin{array}{l}\text { Finished } 7^{\text {th }} \text { Grade } \\
\text { (excludes Bog 97) }\end{array}$ & $\begin{array}{l}.847 \\
(.360)\end{array}$ & $\begin{array}{l}.040 \\
(.020)\end{array}$ & $\begin{array}{l}.031 \\
(.019)\end{array}$ & $\begin{array}{l}.029 \\
(.019)\end{array}$ & $\begin{array}{l}.027 \\
(.018)\end{array}$ & $\begin{array}{l}.025 \\
(.018)\end{array}$ \\
\hline $\begin{array}{l}\text { Finished } 8^{\text {th }} \text { Grade } \\
\text { (excludes Bog } 97 \text { ) }\end{array}$ & $\begin{array}{l}.632 \\
(.483)\end{array}$ & $\begin{array}{l}.112 \\
(.027)\end{array}$ & $\begin{array}{l}.100 \\
(.027)\end{array}$ & $\begin{array}{l}.094 \\
(.027)\end{array}$ & $\begin{array}{l}.077 \\
(.024)\end{array}$ & $\begin{array}{l}.074 \\
(.024)\end{array}$ \\
\hline Repetitions of $6^{\text {th }}$ Grade & $\begin{array}{c}.194 \\
(.454)\end{array}$ & $\begin{array}{l}-.066 \\
(.024)\end{array}$ & $\begin{array}{l}-.059 \\
(.024)\end{array}$ & $\begin{array}{l}-.059 \\
(.024)\end{array}$ & $\begin{array}{l}-.049 \\
(.019)\end{array}$ & $\begin{array}{l}-.049 \\
(.019)\end{array}$ \\
\hline $\begin{array}{l}\text { Ever Repeated after } \\
\text { lottery }\end{array}$ & $\begin{array}{l}.224 \\
(.417)\end{array}$ & $\begin{array}{l}-.060 \\
(.023)\end{array}$ & $\begin{array}{l}-.055 \\
(.023)\end{array}$ & $\begin{array}{l}-.051 \\
(.023)\end{array}$ & $\begin{array}{l}-.055 \\
(.019)\end{array}$ & $\begin{array}{l}-.053 \\
(.019)\end{array}$ \\
\hline $\begin{array}{l}\text { Total Repetitions since } \\
\text { lottery }\end{array}$ & $\begin{array}{l}.254 \\
(.508)\end{array}$ & $\begin{array}{l}-.073 \\
(.028)\end{array}$ & $\begin{array}{l}-.067 \\
(.027)\end{array}$ & $\begin{array}{l}-.064 \\
(.027)\end{array}$ & $\begin{array}{l}-.058 \\
(.022)\end{array}$ & $\begin{array}{l}-.057 \\
(.022)\end{array}$ \\
\hline $\begin{array}{l}\text { Years in School since } \\
\text { lottery }\end{array}$ & $\begin{array}{l}3.7 \\
(.951)\end{array}$ & $\begin{array}{l}.058 \\
(.052)\end{array}$ & $\begin{array}{l}.034 \\
(.050)\end{array}$ & $\begin{array}{l}.031 \\
(.050)\end{array}$ & $\begin{array}{l}.015 \\
(.044)\end{array}$ & $\begin{array}{l}.012 \\
(.043)\end{array}$ \\
\hline Sample Size & 562 & & 1147 & & & \\
\hline
\end{tabular}

Notes: The table reports voucher losers' means and the estimated effect of winning a voucher. Numbers in parentheses are standard deviations in the column of means and standard errors in columns of estimated voucher effects. The samples used to estimate $7^{\text {th }}$ and $8^{\text {th }}$ grade completion effects exclude Bogota 1997. The sample size for these outcomes is 1304 in columns 5-6. The regression estimates are from models that include controls for city, year of application, whether applicant has phone, age, type of survey and instrument, strata of residence, and month of interview. 
Table 4. Educational Outcomes and Voucher Status, By Gender

\begin{tabular}{|c|c|c|c|c|c|c|}
\hline \multirow[t]{5}{*}{ Dependent Variable } & \multicolumn{6}{|c|}{ Coefficient on Voucher Status } \\
\hline & \multicolumn{4}{|c|}{ Bogota 1995} & \multicolumn{2}{|c|}{ Combined Sample } \\
\hline & \multicolumn{2}{|c|}{ Male } & \multicolumn{2}{|c|}{ Female } & \multirow{3}{*}{$\begin{array}{c}\text { Male } \\
\text { Basic } \\
\text { Ctls } \\
(5)\end{array}$} & \multirow{3}{*}{$\begin{array}{c}\text { Female } \\
\text { Basic } \\
\text { Ctls } \\
(6)\end{array}$} \\
\hline & Loser & Basic & Loser & Basic & & \\
\hline & $\begin{array}{l}\text { Means } \\
\text { (1) }\end{array}$ & $\begin{array}{l}\text { Ctls } \\
(2)\end{array}$ & $\begin{array}{l}\text { Means } \\
\text { (3) }\end{array}$ & $\begin{array}{l}\text { Ctls } \\
(4)\end{array}$ & & \\
\hline \multirow[t]{2}{*}{ Started $6^{\text {th }}$ in Private } & .857 & .082 & .897 & .027 & .058 & .077 \\
\hline & $(.351)$ & $(.025)$ & $(.304)$ & $(.021)$ & $(.023)$ & $(.021)$ \\
\hline \multirow[t]{2}{*}{ Started $7^{\text {th }}$ in Private } & .646 & .187 & 699 & .143 & .166 & .177 \\
\hline & (.479) & $(.035)$ & (.460) & $(.033)$ & $(.031)$ & $(.029)$ \\
\hline \multirow{2}{*}{$\begin{array}{l}\text { Currently in Private } \\
\text { School }\end{array}$} & .543 & .136 & .535 & .171 & .124 & .182 \\
\hline & (.499) & $(.039)$ & $(.500)$ & $(.039)$ & $(.033)$ & $(.033)$ \\
\hline \multirow{2}{*}{$\begin{array}{l}\text { Highest Grade } \\
\text { Completed }\end{array}$} & 7.4 & .124 & 7.6 & .140 & .056 & .122 \\
\hline & $(.990)$ & $(.076)$ & (.934) & $(.065)$ & $(.062)$ & $(.052)$ \\
\hline \multirow[t]{2}{*}{ Currently in School } & .843 & -.020 & .819 & .035 & -.026 & .029 \\
\hline & $(.365)$ & $(.029)$ & (.386) & $(.027)$ & $(.024)$ & $(.022)$ \\
\hline \multirow[t]{2}{*}{ Finished $6^{\text {th }}$} & .932 & .014 & .954 & .032 & .003 & .027 \\
\hline & $(.252)$ & $(.018)$ & $(.210)$ & $(.013)$ & $(.017)$ & $(.012)$ \\
\hline \multirow[t]{2}{*}{ Finished $7^{\text {th }}$} & .825 & .026 & .869 & .041 & -.003 & .022 \\
\hline & $(.380)$ & $(.029)$ & (.338) & $(.025)$ & $(.024)$ & $(.020)$ \\
\hline \multirow[t]{2}{*}{ Finished $8^{\text {th }}$} & .589 & .095 & .674 & .105 & .066 & .078 \\
\hline & (.493) & $(.039)$ & $(.470)$ & $(.036)$ & $(.030)$ & $(.027)$ \\
\hline \multirow{2}{*}{$\begin{array}{l}\text { Repetitions of } 6^{\text {th }} \\
\text { grade }\end{array}$} & .229 & -.087 & .160 & -.036 & -.070 & -.033 \\
\hline & $(.506)$ & $(.037)$ & (.395) & $(.030)$ & $(.031)$ & $(.023)$ \\
\hline \multirow{2}{*}{$\begin{array}{l}\text { Ever Repeated after } \\
\text { lottery }\end{array}$} & .254 & -.083 & .195 & -.029 & -.076 & -.035 \\
\hline & $(.436)$ & $(.034)$ & $(.370)$ & $(.031)$ & $(.028)$ & $(.025)$ \\
\hline \multirow{2}{*}{$\begin{array}{l}\text { Total Repetitions } \\
\text { since lottery }\end{array}$} & .296 & -.101 & .213 & -.031 & -.079 & -.037 \\
\hline & $(.550)$ & $(.042)$ & (.459) & $(.033)$ & $(.035)$ & $(.026)$ \\
\hline \multirow{2}{*}{$\begin{array}{l}\text { Calendar Years in } \\
\text { School since lottery }\end{array}$} & 3.7 & -.029 & 3.6 & .091 & -.041 & .081 \\
\hline & $(.962)$ & $(.077)$ & $(.941)$ & $(.063)$ & $(.067)$ & $(.055)$ \\
\hline Sample Size & 280 & 575 & 282 & 572 & 779 & 798 \\
\hline
\end{tabular}

Notes: The table reports voucher losers' means and the estimated effect of winning a voucher.

Numbers in parentheses are standard deviations in columns of means and standard errors in columns of estimated voucher effects. The regression estimates are from models that include controls for city, year of application, whether applicant has phone, age, type of survey and instrument, strata of residence, and month of interview. 
Table 5. Test Results

\begin{tabular}{|c|c|c|c|c|c|}
\hline & $\begin{array}{c}\text { OLS } \\
\text { Results } \\
\\
(1) \\
\end{array}$ & $\begin{array}{c}\text { OLS } \\
\text { Results } \\
\text { with } \\
\text { Covariates } \\
\text { (2) } \\
\end{array}$ & RE & $\begin{array}{c}\mathrm{RE} \\
\text { With } \\
\text { Covariates } \\
\\
(4) \\
\end{array}$ & $\begin{array}{c}\text { Sample } \\
\text { Sizes } \\
\\
(5) \\
\end{array}$ \\
\hline \multicolumn{6}{|c|}{ A. Test Scores for All Applicants } \\
\hline Total Points & $\begin{array}{c}.217 \\
(.116)\end{array}$ & $\begin{array}{c}.205 \\
(.108)\end{array}$ & & & 282 \\
\hline Math Scores & $\begin{array}{l}.178 \\
(.120)\end{array}$ & $\begin{array}{l}.153 \\
(.114)\end{array}$ & & & 282 \\
\hline Reading Scores & $\begin{array}{c}.204 \\
(.115)\end{array}$ & $\begin{array}{c}.203 \\
(.114)\end{array}$ & & & 283 \\
\hline Writing Scores & $\begin{array}{l}.126 \\
(.116)\end{array}$ & $\begin{array}{l}.128 \\
(.105)\end{array}$ & & & 283 \\
\hline Pooled Test Scores & & & $\begin{array}{c}.170 \\
(.095)\end{array}$ & $\begin{array}{c}.148 \\
(.088)\end{array}$ & 846 \\
\hline Math and Reading Scores & & & $\begin{array}{c}.192 \\
(.101)\end{array}$ & $\begin{array}{c}.162 \\
(.096)\end{array}$ & 568 \\
\hline \multicolumn{6}{|c|}{ B. Test Scores for Female Applicants } \\
\hline Total Points & $\begin{array}{l}.199 \\
(.162)\end{array}$ & $\begin{array}{c}.263 \\
(.126)\end{array}$ & & & 146 \\
\hline Math Scores & $\begin{array}{c}.292 \\
(.145)\end{array}$ & $\begin{array}{c}.346 \\
(.141)\end{array}$ & & & 146 \\
\hline Reading Scores & $\begin{array}{l}.117 \\
. .158)\end{array}$ & $\begin{array}{l}.152 \\
(.136)\end{array}$ & & & 147 \\
\hline Math and Reading Scores & & & $\begin{array}{c}.204 \\
(.130)\end{array}$ & $\begin{array}{c}.235 \\
(.117)\end{array}$ & 293 \\
\hline \multicolumn{6}{|c|}{ C. Test Scores for Male Applicants } \\
\hline Total Points & $\begin{array}{c}.204 \\
(.169)\end{array}$ & $\begin{array}{l}.170 \\
(.189)\end{array}$ & & & 134 \\
\hline Math Scores & $\begin{array}{c}.010 \\
(.178)\end{array}$ & $\begin{array}{c}.004 \\
(.187)\end{array}$ & & & 134 \\
\hline Reading Scores & $\begin{array}{c}.276 \\
(.183)\end{array}$ & $\begin{array}{c}.220 \\
(.190)\end{array}$ & & & 134 \\
\hline Math and Reading Scores & & & $\begin{array}{c}.143 \\
(.160)\end{array}$ & $\begin{array}{c}.087 \\
(.160)\end{array}$ & 268 \\
\hline
\end{tabular}

Notes: Robust standard errors are reported in parentheses. Standard errors in Columns 1 and 2 are corrected for within-school-of-application clustering. Test scores are in standard deviation units. The estimates in columns $2 \& 4$ are from models that include controls for applicant's age, gender, parents' schooling, strata of residence and type of survey and instrument. Columns $3 \& 4$ models include random effects for each test subject. The sample for "Pooled Test Scores" includes 3 observations per student (one for each subject) while "Math and Reading Scores" includes two observations per student. 
Table 6. Non-Educational Outcomes and Voucher Status

\begin{tabular}{|c|c|c|c|c|c|c|}
\hline \multirow[t]{3}{*}{ Dependent Variable } & \multicolumn{6}{|c|}{ Coefficient on Voucher Status } \\
\hline & \multicolumn{3}{|c|}{ Bogota 95} & \multicolumn{3}{|c|}{ Combined Sample } \\
\hline & $\begin{array}{c}\text { Losers' } \\
\text { Means } \\
\text { (1) }\end{array}$ & $\begin{array}{c}\text { Basic } \\
\text { Controls } \\
(2)\end{array}$ & $\begin{array}{l}\text { Probit w/ } \\
\text { Basic } \\
\text { Controls } \\
\text { (3) }\end{array}$ & $\begin{array}{c}\text { Losers' } \\
\text { Means } \\
\text { (4) }\end{array}$ & $\begin{array}{c}\text { Basic } \\
\text { Controls } \\
(5)\end{array}$ & $\begin{array}{l}\text { Probit w/ } \\
\text { Basic } \\
\text { Controls } \\
(6)\end{array}$ \\
\hline \multicolumn{7}{|l|}{ A. Male and Female } \\
\hline $\begin{array}{l}\text { Married or Living w/ } \\
\text { Companion }\end{array}$ & $\begin{array}{l}.0160 \\
(.1256)\end{array}$ & $\begin{array}{l}-.0087 \\
(.0059)\end{array}$ & $\begin{array}{l}-.0066 \\
(.0038)\end{array}$ & $\begin{array}{l}.0171 \\
(.1297)\end{array}$ & $\begin{array}{l}-.0094 \\
(.0056)\end{array}$ & $\begin{array}{l}-.0065 \\
(.0034)\end{array}$ \\
\hline Has Child & $\begin{array}{l}.0338 \\
(.1809)\end{array}$ & $\begin{array}{l}-.0103 \\
(.0096)\end{array}$ & $\begin{array}{l}-.0079 \\
(.0075)\end{array}$ & $\begin{array}{l}.0303 \\
(.1714)\end{array}$ & $\begin{array}{l}-.0069 \\
(.0079)\end{array}$ & $\begin{array}{l}-.0055 \\
(.0062)\end{array}$ \\
\hline $\begin{array}{l}\text { Applicant is } \\
\text { Working }\end{array}$ & $\begin{array}{l}.1690 \\
(.3751)\end{array}$ & $\begin{array}{l}-.0297 \\
(.0205)\end{array}$ & $\begin{array}{l}-.0299 \\
(.0184)\end{array}$ & $\begin{array}{l}.1616 \\
(.3684)\end{array}$ & $\begin{array}{l}-.02651 \\
(.0171)\end{array}$ & $\begin{array}{l}-.0254 \\
(.0153)\end{array}$ \\
\hline Number of Hours & 4.881 & -1.222 & -- & 4.417 & -.8699 & -- \\
\hline Working & $(12.3)$ & $(.6441)$ & -- & $(11.60)$ & $(.5235)$ & -- \\
\hline Sample Size & 562 & 1147 & 1147 & 760 & 1577 & 1577 \\
\hline \multicolumn{7}{|l|}{ B. Male } \\
\hline $\begin{array}{l}\text { Married or Living w/ } \\
\text { Companion }\end{array}$ & $\begin{array}{l}.0036 \\
(.0598)\end{array}$ & $\begin{array}{l}-.0039 \\
(.0038)\end{array}$ & $\begin{array}{l}-- \\
--\end{array}$ & $\begin{array}{l}.0027 \\
(.0518)\end{array}$ & $\begin{array}{l}-.0027 \\
(.0026)\end{array}$ & $\begin{array}{l}-- \\
--\end{array}$ \\
\hline $\begin{array}{l}\text { Applicant is } \\
\text { Working }\end{array}$ & $\begin{array}{c}.2321 \\
(.4230)\end{array}$ & $\begin{array}{l}-.0366 \\
(.0331)\end{array}$ & $\begin{array}{l}-.0336 \\
(.0324)\end{array}$ & $\begin{array}{c}.2252 \\
(.4183)\end{array}$ & $\begin{array}{l}-.0283 \\
(.0278)\end{array}$ & $\begin{array}{l}-.0294 \\
(.0261)\end{array}$ \\
\hline $\begin{array}{l}\text { Number of Hours } \\
\text { Working }\end{array}$ & $\begin{array}{c}6.421 \\
(13.69)\end{array}$ & $\begin{array}{l}-.6376 \\
(1.072)\end{array}$ & $\begin{array}{l}-- \\
--\end{array}$ & $\begin{array}{c}6.198 \\
(13.31)\end{array}$ & $\begin{array}{l}-.6231 \\
(.8859)\end{array}$ & $\begin{array}{l}-- \\
--\end{array}$ \\
\hline Sample Size & 280 & 575 & 575 & 373 & 779 & 778 \\
\hline \multicolumn{7}{|l|}{ C. Female } \\
\hline $\begin{array}{l}\text { Married or Living w/ } \\
\text { Companion }\end{array}$ & $\begin{array}{l}.0284 \\
(.1663)\end{array}$ & $\begin{array}{l}-.0100 \\
(.0113)\end{array}$ & $\begin{array}{l}-.0112 \\
(.0078)\end{array}$ & $\begin{array}{l}.0309 \\
(.1733)\end{array}$ & $\begin{array}{l}-.0113 \\
(.0109)\end{array}$ & $\begin{array}{l}-.0114 \\
(.0068)\end{array}$ \\
\hline $\begin{array}{l}\text { Pregnant or Has } \\
\text { Child }\end{array}$ & .0603 & -.0151 & -.0155 & .0541 & -.0092 & -.0119 \\
\hline Applicant is & .1064 & -.0314 & -.0262 & .1005 & -.0317 & -.0240 \\
\hline Working & $(.3089)$ & $(.0235)$ & $(.0189)$ & $(.3011)$ & $(.0196)$ & $(.0156)$ \\
\hline Number of Hours & 3.351 & -2.116 & -- & 2.704 & -1.499 & -- \\
\hline Working & $(10.57)$ & $(.6527)$ & -- & $(9.36)$ & $(.5240)$ & -- \\
\hline Sample Size & 282 & 572 & 572 & 388 & 798 & 798 \\
\hline
\end{tabular}

Notes: Numbers in parentheses are standard deviations in columns of means and standard errors in columns of estimated voucher effects. Results are for samples with non-missing non-educational and educational outcomes. Columns 2 and 3 show results from models that control for whether applicants had access to a phone, age, gender, type of survey and instrument, strata of residence, and month of interview. Columns 5 and 6 also include controls for city and year of application. 
Table 7. OLS and 2SLS Estimates of the Effect of Ever Using a Private School Scholarship

\begin{tabular}{|c|c|c|c|c|c|}
\hline \multirow[t]{5}{*}{ Dependent Variable } & \multicolumn{5}{|c|}{ Coefficient on Ever Used a Private School Scholarship } \\
\hline & \multicolumn{3}{|c|}{ Bogota 95} & \multicolumn{2}{|c|}{ Combined Sample } \\
\hline & Loser & OLS & 2SLS & OLS & 2 SLS \\
\hline & Mean & & & & \\
\hline & $(1)$ & $(2)$ & $(3)$ & $(4)$ & $(5)$ \\
\hline Highest Grade & 7.5 & .167 & (196 & 1.141 & 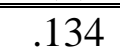 \\
\hline Completed & $(.965)$ & $(.053)$ & $(.078)$ & $(.042)$ & $(.065)$ \\
\hline \multirow[t]{2}{*}{ In School } & .831 & .021 & .010 & .033 & -.003 \\
\hline & $(.375)$ & $(.021)$ & $(.031)$ & $(.017)$ & $(.026)$ \\
\hline Total Repetitions since & .254 & -.077 & -.100 & -.069 & -.091 \\
\hline lottery & $(.508)$ & $(.029)$ & $(.042)$ & $(.023)$ & $(.035)$ \\
\hline \multirow[t]{2}{*}{ Finished $8^{\text {th }}$} & .632 & .114 & .151 & .108 & .127 \\
\hline & $(.483)$ & $(.028)$ & $(.041)$ & $(.025)$ & $(.038)$ \\
\hline \multirow{2}{*}{$\begin{array}{l}\text { Test Scores - Total } \\
\text { Points }\end{array}$} & -.099 & .379 & .291 & -- & - \\
\hline & $(1.0)$ & $(.111)$ & $(.153)$ & & \\
\hline \multirow{2}{*}{$\begin{array}{l}\text { Married or Living w/ } \\
\text { Companion }\end{array}$} & .016 & -.009 & -.013 & -.010 & -.014 \\
\hline & $(.126)$ & $(.006)$ & $(.009)$ & $(.006)$ & $(.009)$ \\
\hline $\mathrm{N}$ & 562 & \multicolumn{2}{|c|}{1147} & \multicolumn{2}{|c|}{1577} \\
\hline
\end{tabular}

Notes: The table reports loser means and OLS and 2SLS estimates of the effect of ever having used a private school scholarship. Results are from models that control for city, year of application, whether applicant had access to a phone, age, type of survey and instrument, strata of residence, and month of interview. Robust standard errors are reported in parentheses. Data for the outcome "Finished $8^{\text {th }}$ " in the combined sample does not include applicants to the Bogota 1997 voucher lottery. For the outcome "Test Scores - Total Points," the sample is restricted to those individuals who took the exam. In the 2sls specification, the endogenous regressor used scholarship is instrumented with voucher status. 
Table 8. Matriculation, Tuition Fees and Voucher Status for Bogota 1995 Applicants

\begin{tabular}{|c|c|c|c|c|c|c|}
\hline \multirow[t]{2}{*}{ Variable } & \multicolumn{3}{|c|}{ Full Sample } & \multicolumn{3}{|c|}{$\begin{array}{l}\text { Conditional on Private } \\
\text { School Attendance }\end{array}$} \\
\hline & $\begin{array}{l}\text { Loser } \\
\text { Means } \\
(1) \\
\end{array}$ & $\begin{array}{c}\text { No Ctls } \\
(2)\end{array}$ & $\begin{array}{c}\text { Basic Ctls } \\
(3) \\
\end{array}$ & $\begin{array}{c}\text { Loser } \\
\text { Means } \\
(4) \\
\end{array}$ & $\begin{array}{c}\text { No Ctls } \\
(5) \\
\end{array}$ & $\begin{array}{c}\text { Basic Ctls } \\
(6) \\
\end{array}$ \\
\hline $\begin{array}{l}\text { Using any Scholarship in } \\
\text { Survey Year }\end{array}$ & $\begin{array}{l}.054 \\
(.227)\end{array}$ & $\begin{array}{l}.497 \\
(.023)\end{array}$ & $\begin{array}{l}.494 \\
(.023)\end{array}$ & $\begin{array}{l}.085 \\
(.279)\end{array}$ & $\begin{array}{l}.709 \\
(.027)\end{array}$ & $\begin{array}{l}.696 \\
(.028)\end{array}$ \\
\hline Currently In Private School & $\begin{array}{l}.530 \\
(.500)\end{array}$ & $\begin{array}{l}.156 \\
(.029)\end{array}$ & $\begin{array}{l}.152 \\
(.028)\end{array}$ & 1 & -- & -- \\
\hline Currently In Public School & $\begin{array}{l}.290 \\
(.454)\end{array}$ & $\begin{array}{l}-.140 \\
(.025)\end{array}$ & $\begin{array}{l}-.146 \\
(.025)\end{array}$ & 0 & -- & -- \\
\hline Scholarship Value & $\begin{array}{c}16.0 \\
(64.2)\end{array}$ & $\begin{array}{l}74.3 \\
(5.4)\end{array}$ & $\begin{array}{l}72.6 \\
(5.4)\end{array}$ & $\begin{array}{c}29.8 \\
(85.8)\end{array}$ & $\begin{array}{l}101.8 \\
(7.6)\end{array}$ & $\begin{array}{l}98.1 \\
(7.9)\end{array}$ \\
\hline $\begin{array}{l}\text { Scholarship Value } \\
\quad(\text { Conditional on }>0)\end{array}$ & $\begin{array}{c}199.0 \\
(122.4)\end{array}$ & $\begin{array}{l}-13.3 \\
(19.1)\end{array}$ & $\begin{array}{l}-11.3 \\
(18.5)\end{array}$ & $\begin{array}{c}211.1 \\
(118.2)\end{array}$ & $\begin{array}{l}-25.5 \\
(19.1)\end{array}$ & $\begin{array}{l}-22.0 \\
(18.5)\end{array}$ \\
\hline Gross School Fees & $\begin{array}{c}191.5 \\
(188.3)\end{array}$ & $\begin{array}{l}52.3 \\
(10.2)\end{array}$ & $\begin{array}{c}48.1 \\
(11.0)\end{array}$ & $\begin{array}{c}332.2 \\
(133.6)\end{array}$ & $\begin{array}{l}11.0 \\
(10.7)\end{array}$ & $\begin{array}{c}9.8 \\
(10.7)\end{array}$ \\
\hline Net School Fees & $\begin{array}{c}175.9 \\
(185.6)\end{array}$ & $\begin{array}{l}-22.0 \\
(11.5)\end{array}$ & $\begin{array}{l}-24.5 \\
(9.9)\end{array}$ & $\begin{array}{c}302.4 \\
(154.3)\end{array}$ & $\begin{array}{l}-90.7 \\
(11.6)\end{array}$ & $\begin{array}{l}-88.2 \\
(11.7)\end{array}$ \\
\hline $\begin{array}{l}\text { Gross School Fees for } \\
\text { Public Schools }\end{array}$ & $\begin{array}{c}54.6 \\
(109.4)\end{array}$ & $\begin{array}{c}3.2 \\
(13.4)\end{array}$ & $\begin{array}{c}1.0 \\
(13.8)\end{array}$ & -- & -- & -- \\
\hline $\begin{array}{l}\text { Currently Using Scholarship } \\
\text { from the Private School }\end{array}$ & $\begin{array}{l}.031 \\
(.173)\end{array}$ & $\begin{array}{l}-.008 \\
(.011)\end{array}$ & $\begin{array}{l}-.010 \\
(.012)\end{array}$ & $\begin{array}{c}.059 \\
(.235)\end{array}$ & $\begin{array}{c}-.026 \\
(.019)\end{array}$ & $\begin{array}{l}-.031 \\
(.020)\end{array}$ \\
\hline Sample Size & 534 & 1085 & 1085 & 283 & 661 & 664 \\
\hline
\end{tabular}

Notes: The table reports voucher losers' means and the estimated effect of winning a voucher.

Numbers in parentheses are standard deviations in columns of means and standard errors in columns of estimated voucher effects. Sample sizes differ from other tables because of missing fee data. The sample sizes differ slightly across rows because of missing data for "Currently Using Scholarship from the Private School" and the outcomes with the more comprehensive fee measure. The regression estimates in columns 3 and 6 are from models that include controls for whether applicants had access to a phone, age, type of survey and instrument, strata of residence, and month of interview. 
Table 9. Lower/Upper Bounds of Voucher Effects on Matriculation and Tuition Fees for Bogota 1995 Applicants Who Would Have Attended Private School and Paid More Than Cutoff Fees

\begin{tabular}{|c|c|c|c|c|c|c|}
\hline $\begin{array}{l}\text { Dollar } \\
\text { Cutoff }\end{array}$ & $\begin{array}{l}\text { Corresponding } \\
\text { Quantile of } \\
\text { Losers' Fee } \\
\text { Distribution } \\
\text { (1) }\end{array}$ & $\begin{array}{c}\text { Losers'Avg } \\
\text { Fee Above } \\
\text { Quantile } \\
\text { (2) }\end{array}$ & $\begin{array}{c}\text { Losers' } \\
\text { Probability of } \\
\text { Priv School } \\
\text { Attendance } \\
\text { (3) }\end{array}$ & $\begin{array}{c}\text { Losers'Avg } \\
\text { Priv School } \\
\text { Fee Above } \\
\text { Cutoff } \\
\text { (4) }\end{array}$ & $\begin{array}{l}\text { Upper } \\
\text { Bound }\end{array}$ & $\begin{array}{l}\text { Lower } \\
\text { Bound }\end{array}$ \\
\hline 190.0 & $52^{\text {nd }}$ Percentile & $\begin{array}{c}370.5 \\
(104.7)\end{array}$ & $\begin{array}{c}.973 \\
(.163)\end{array}$ & $\begin{array}{l}368.1 \\
(95.1)\end{array}$ & $\begin{array}{l}38.4 \\
(9.5)\end{array}$ & $\begin{array}{c}2.9 \\
(8.9)\end{array}$ \\
\hline 283.2 & $60^{\text {th }}$ Percentile & $\begin{array}{l}396.7 \\
(94.4)\end{array}$ & $\begin{array}{c}.981 \\
(.136)\end{array}$ & $\begin{array}{l}392.5 \\
(83.0)\end{array}$ & $\begin{array}{l}31.4 \\
(9.7)\end{array}$ & $\begin{array}{c}9.2 \\
(8.8)\end{array}$ \\
\hline 335.8 & $70^{\text {th }}$ Percentile & $\begin{array}{l}424.8 \\
(92.7)\end{array}$ & $\begin{array}{c}.981 \\
(.136)\end{array}$ & $\begin{array}{l}419.3 \\
(78.7)\end{array}$ & $\begin{array}{c}32.1 \\
(11.3)\end{array}$ & $\begin{array}{c}17.7 \\
(10.0)\end{array}$ \\
\hline 370.1 & $80^{\text {th }}$ Percentile & $\begin{array}{l}460.2 \\
(96.0)\end{array}$ & $\begin{array}{c}.972 \\
(.167)\end{array}$ & $\begin{array}{l}452.8 \\
(78.3)\end{array}$ & $\begin{array}{l}36.5 \\
(9.3)\end{array}$ & $\begin{array}{c}14.0 \\
(12.3)\end{array}$ \\
\hline 427.0 & $90^{\text {th }}$ Percentile & $\begin{array}{c}523.3 \\
(101.0)\end{array}$ & $\begin{array}{c}.943 \\
(.233)\end{array}$ & $\begin{array}{l}511.9 \\
(74.5)\end{array}$ & $\begin{array}{c}48.3 \\
(16.8)\end{array}$ & $\begin{array}{c}27.7 \\
(18.3)\end{array}$ \\
\hline
\end{tabular}

Notes: The upper bound above a given percentile is computed in a two-step process. First, we estimate the difference between winners' and losers' matriculation fees conditional on being greater than the given quantile in their respective distributions. Second, we divide this difference by the probability that losers above the given percentile attend private school. The lower bound above a cutoff is computed by differencing winners' and losers' fees conditional on private school attendance and conditional on being greater than the cutoff. See text for further details. 